
Chapter B

\section{Mineral Resources of the Paria-Hackberry Wilderness Study Area, Kane County, Utah}

By HENRY BELL III, ALFRED L. BUSH, ROBERT L. TURNER, and JOHN W. CADY U.S. Geological Survey

S. DON BROWN, BRIAN J. HANNIGAN, and JOHN R. THOMPSON

U.S. Bureau of Mines

An assessment of the likelihood of occurrence of metallic, nonmetallic, and oil and gas concentrations 


\section{U.S. DEPARTMENT OF THE INTERIOR}

MANUEL LUJAN, JR., Secretary

\section{U.S. GEOLOGICAL SURVEY}

Dallas L. Peck, Director

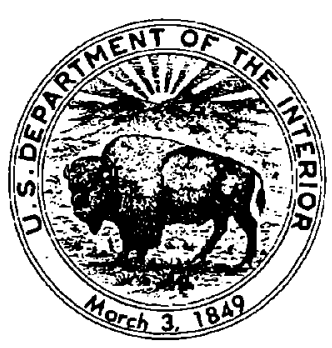

Any use of trade, product, or firm names in this publication is for descriptive

purposes only and does not imply endorsement by the U.S. Government.

UNITED STATES GOVERNMENT PRINTING OFFICE: 1991

For sale by the

Books and Open-File Reports Section

U.S. Geological Survey

Federal Center

Box 25425

Denver, CO 80225

\section{Library of Congress Cataloging-in-Publication Data}

Minera! resources of the Paria-Hackberry wilderness study area, Kane County, Utah / by Henry Bell III ... let al.].

p. $\quad \mathrm{cm}$. - (Mineral resources of wilderness study areas-the Cockscomb

region, Utah; ch. B) (U.S. Geological Survey bulletin ; 1748-B) (Studies

related to wilderness)

Includes bibliographical references.

Supt. of Docs. no.: 1 19.3:1748B

1. Mines and mineral resources-Utah-Paria-Wilderness.

2. Paria-Hackberry Wilderness (Utah) I. Bell, Henry, 1923-1989. II. Series.

III. Series: U.S. Geological Survey bulletin ; 1748-B. IV. Series: Studies related to wilderness.

QE75.B9

no. $1748-B$

[TN24.U8]

$557.3 \mathrm{~s}-\mathrm{dc} 20$

$91-17067$

[553'.09792'51] 


\section{STUDIES RELATED TO WILDERNESS}

Bureau of Land Management Wilderness Study Areas

The Federal Land Policy and Management Act (Public Law 94-579, October 21, 1976) requires the U.S. Geological Survey and the U.S. Bureau of Mines to conduct mineral surveys on certain areas to determine the mineral values, if any, that may be present. Results must be available to the public and be submitted to the President and the Congress. This report presents the results of a mineral survey of the Paria-Hackberry (UT-040-247) Wilderness Study Area, Kane County, Utah. 



\section{FOREWORD}

Henry Bell III, the senior author of this report, died suddenly in October 1989. He had taken responsibility for this study when physical problems prevented the original assignee, A.L. Bush, from conducting the field investigation. After Bell's death, Bush resumed the task of completing the study. Although much of the following report was written by Bell, Bush assumes full responsibility for any errors or omissions that may be present. There is no question that Bell, had he lived, would have presented an exemplary report. 



\section{CONTENTS}

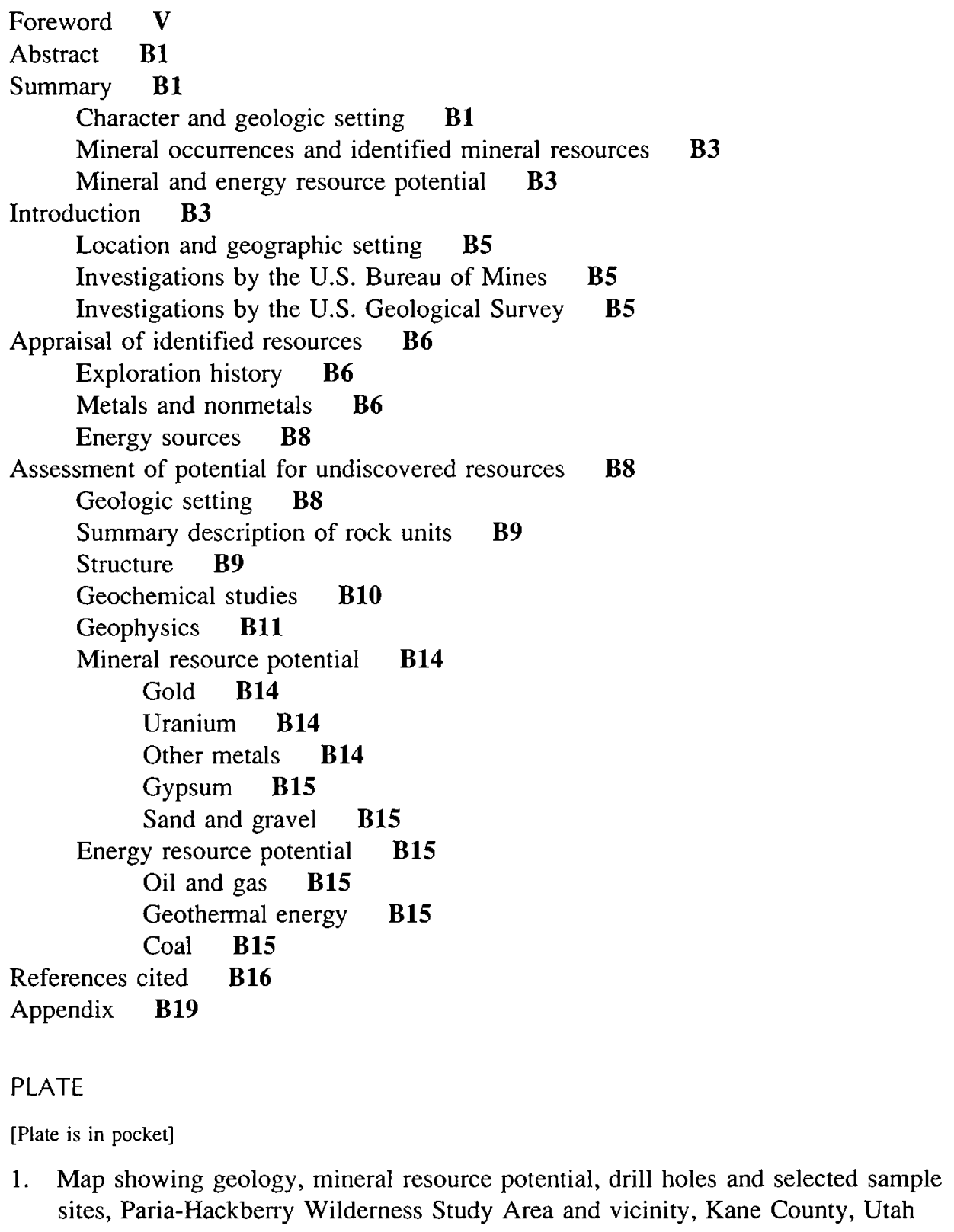

1. Map showing geology, mineral resource potential, drill holes and selected sample sites, Paria-Hackberry Wilderness Study Area and vicinity, Kane County, Utah

\section{FIGURES}

1-5. Maps of the Paria-Hackberry Wilderness Study Area, Kane County, Utah:

1. Location B2

2. Mineral and energy resource potential B4

3. Oil and gas leases, unpatented mining claims, and oil and (or) gas drill holes $\quad$ B7

4. Complete Bouguer gravity anomaly B12

5. Residual total-field aeromagnetic B13 



\title{
Mineral Resources of the Paria-Hackberry Wilderness Study Area, Kane County, Utah
}

\author{
By Henry Bell III, Alfred L. Bush, Robert L. Turner, and John W. Cady \\ U.S. Geological Survey
}

S. Don Brown, Brian J. Hannigan, and John R. Thompson

U.S. Bureau of Mines

\begin{abstract}
The Paria-Hackberry Wilderness Study Area, in central Kane County, southern Utah, is a region of generally flat-lying, gently folded sedimentary rocks, bounded on the east by the east-dipping limb of the East Kaibab monocline and cut by sheer-walled, narrow canyons. The area selected for study by the U.S. Bureau of Land Management totaled 94,642 acres (148 square miles); because of uncertainty as to final boundaries, the U.S. Geological Survey studied an additional contiguous 41,180 acres (64 square miles). No identified resources of metals or nonmetallic minerals are present in the study area. An unsuccessful attempt to recover "flour" gold from the Chinle Formation was made at the now-abandoned townsite of Paria. The mineral resource potential for all metals, including gold, uranium, barium, silver, strontium, arsenic, antimony, mercury, copper, manganese, cadmium, and zinc, is low for the entire wilderness study area. The likelihood of occurrence of "decorative-use" gypsum and of sand and gravel is moderate in limited areas of the northern part of the Paria-Hackberry Wilderness Study Area and, for sand and gravel, in a few small occurrences along the Paria River valley. A moderate energy resource potential is assessed for oil and gas and a low potential for geothermal energy, for the entire study area. There is no energy resource potential for coal.
\end{abstract}

\section{SUMMARY}

At the request of the U.S. Bureau of Land Management (BLM) the U.S. Geological Survey (USGS) and the U.S. Bureau of Mines (USBM), studied 94,642 acres (148 square miles) of

Manuscript approved for publication February 5, 1991. the Paria-Hackberry Wilderness Study Area (UT-040-247) in Kane County, southern Utah (fig. 1) to appraise their identified mineral resources and assess the mineral resource potential. The USGS studied an additional 41,180 acres (64 square miles) that are contiguous to the area finally selected by the BLM (fig. 1). In this report the total area studied is called the "wilderness study area," "study area," or "Paria-Hackberry area" as appropriate. The Paria-Hackberry area is mostly a terrane of flat-lying, in places gently warped, sedimentary rocks, including on the east side a narrow strip of the steeply east-dipping East Kaibab monocline. The study area adjoins the Wahweap (UT-040-248) Wilderness Study Area to the east and is near the Cockscomb (UT-040-275) Wilderness Study Area to the south, both reported on in Bell and others (1990).

\section{Character and Geologic Setting}

The study area is in the Colorado Plateau physiographic province, west of the Kaiparowits Plateau, on the Kaibab uplift. This part of the High Plateaus of Utah is characterized by narrow, deep canyons separated from nearby mesas by broad, undulating benches that rise in steps from an elevation of about 4,000 to 7,000 ft (feet). In this region, the Paria River and Hackberry Creek are dry much of the time; their seasonally dry beds, passable for field vehicles, supplement access from unpaved county roads and from U.S. Highway 89, which passes near the southern boundary of the study area. On the Kaibab uplift west of the East Kaibab monocline and west of Cottonwood Creek (fig. 1), the oldest exposed rocks are Permian in age (see geologic time chart in Appendix) and are mostly limestones that constitute the Kaibab Limestone, exposed in stratigraphic windows eroded through soft reddish sandstone and shale of the Triassic Moenkopi Formation. Unconformably above the Moenkopi Formation are variegated 


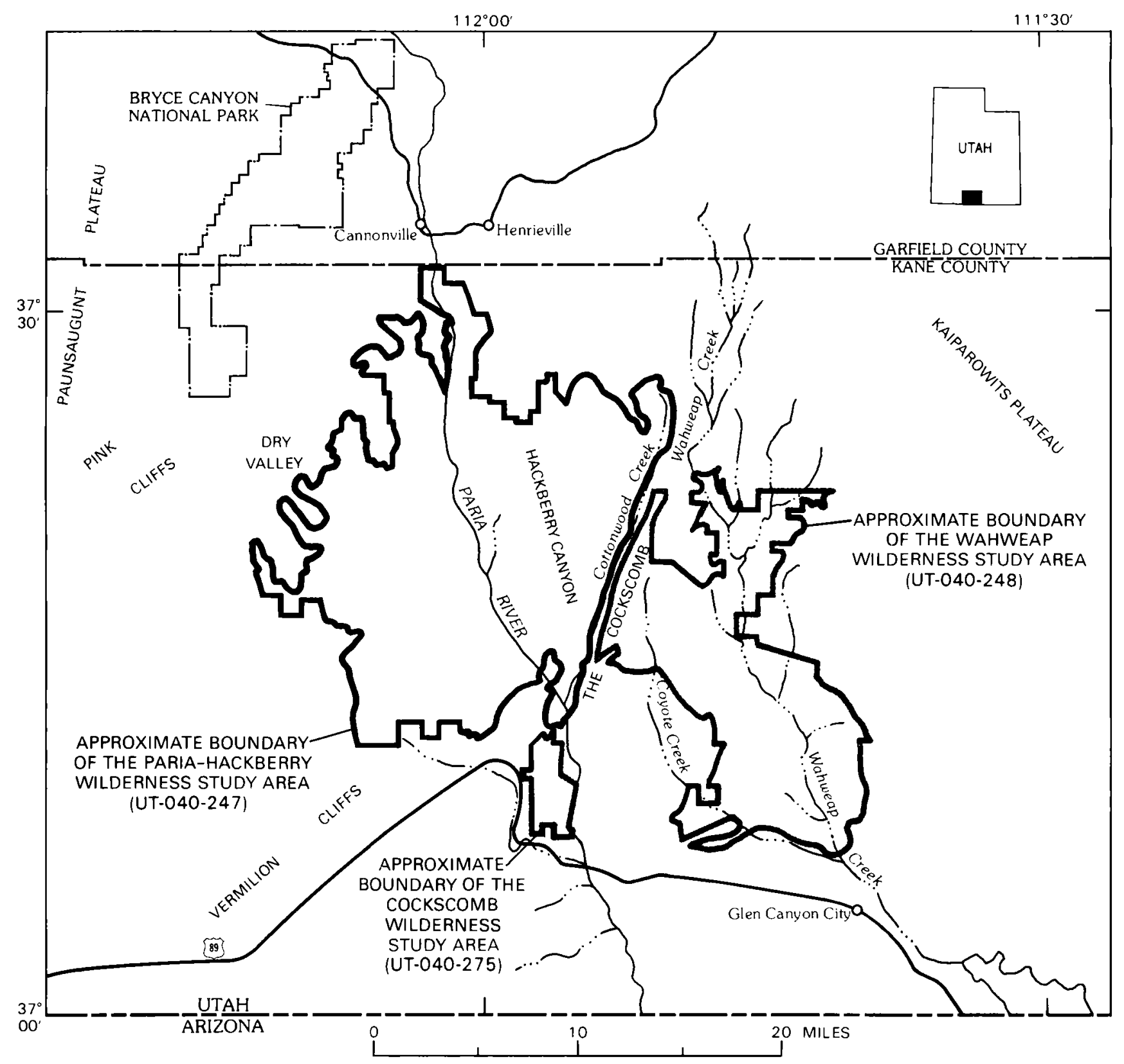

Figure 1. Index map of the Paria-Hackberry Wilderness Study Area, Kane County, Utah. Boundary includes additional continuous acreage studied by the U.S. Geological Survey as discussed in text and shown on plate 1. The Cockscomb and Wahweap Wilderness Study Areas are not discussed in this report but are shown for location only.

clayey sandstone, shale, and local, lenticular, coarse sandstone of the Triassic Chinle Formation. Above the Chinle Formation are generally light-colored or white, crossbedded sandstones that, following the usage of Peterson and Pipiringos (1979), are successively the Jurassic Moenave Formation, Kayenta Formation, and Navajo Sandstone. These form cliffs ranging from 600 to $1,000 \mathrm{ft}$ in height. Numerous narrow canyons, including the canyon of the Paria River and Hackberry Canyon, have been cut into these formations. Above the Navajo Sandstone lie mudstone; slabby sandstone; limestone with gypsum beds; and soft, fine-grained, light-colored sandstone forming rounded cliffs in the Thousand Pockets Tongue of the Page Sandstone, and the interfingering Jurassic Carmel Formation and Entrada Sandstone. East of The Cockscomb (fig. 1), the Entrada is overlain by the coal-bearing, Cretaceous Dakota Sandstone. A widespread unconformity at the base of the Dakota has cut out rocks equivalent to the Summerville Formation and the Morrison Formation, which underlie the Dakota farther to the east, outside the study area. The rocks plunge northward along the East Kaibab monocline so that older rocks can be seen covered successively by younger rocks, which lie uneroded on both sides of the 
monocline, preserving the steeply dipping structure. Along the monocline the softer mudstone and shale have been eroded, leaving the more resistant sandstones as hogbacks and cockscomblike ridges.

Steeply east-dipping rocks in the East Kaibab monocline separate nearly flat-lying strata on the west from nearly flatlying strata on the east that are as much as 7,000 ft stratigraphically higher. Faults and fractures are abundant along the monocline; many closely spaced faults trend generally northnortheast along the strike of the beds, and some trend to the northeast, fragmenting and offsetting the steeply dipping beds. Other faults trend northwest, such as those along the Paria River and Hackberry Canyon. Associated with many of these faults and fractures are iron-oxide-stained rocks and carbonate-cemented rocks, particularly in the Cockscomb area, where prospecting for copper minerals has occurred. The nearly flat-lying rocks east and west of the East Kaibab monocline are gently folded and have north- northeasttrending, sinuous fold axes; some of the folds have been tested for oil and gas. Widespread unconformities truncating the folded rocks also have been folded, creating possible sites of hydrocarbon accumulation along the unconformities in the study area.

\section{Mineral Occurrences and Identified Mineral Resources}

No identified resources of metallic minerals occur in the study area. Placer mining for gold was attempted along the Paria River, and prospects for copper, lead, manganese, titanium, and uranium are evident in and near the study area. Gypsum is mined sporadically at a quarry about $1 \mathrm{mi}$ (mile) northeast of the northern corner of the study area. There are no other occurrences of noteworthy industrial rocks or nonmetallic minerals.

\section{Mineral and Energy Resource Potential}

The resource potential of the study area is summarized in figure 2. Gold occurs in the Chinle Formation as very fine grained (flour) particles (Lawson, 1913; Gregory, 1948), but it was not detected by chemical analyses of rock or streamsediment samples in the study area. The resource potential for gold deposits in the Chinle Formation is judged to be low, at certainty level $\mathrm{C}$. The resource potential for gold deposits in all other formations in the study area is also low, at certainty level $\mathrm{C}$.

Uranium deposits occur elsewhere in the predominantly clay-rich Chinle Formation, especially in sandstones and conglomerates that form stream-channel deposits containing carbonaceous plant remains. The Chinle crops out in the study area, but the sandstone-shale ratio is low and not characteristic of the ore-bearing Chinle elsewhere. In addition, no high values for uranium were found in geochemical samples collected in the vicinity; the resource potential for undiscovered uranium deposits is low, at certainty level C.

The geologic environment in the vicinity of the study area is characterized by gypsum beds, impure limestones, and red sandstone with traces of copper minerals, through which fluids have moved along fractures. Although this environment is permissive for the formation of metal-bearing vein deposits, only a low mineral resource potential, at certainty level $B$, is indicated for metals in vein deposits because of the low metal values in a few of the samples collected. A few metallic elements-such as barium, silver, strontium, arsenic, antimony, mercury, copper, manganese, cadmium, and zincoccur in samples from three widely dispersed areas in anomalously high concentrations. In general, however, the values are low and the samples generally scattered; in the absence of other factors no more than low mineral resource potential, at a certainty level of $C$, can be assessed overall for undiscovered deposits of metals in the study area.

The occurrence of a 25 -ft-thick bed of gypsum in the Carmel Formation just outside the study area indicates a moderate mineral resource potential for "decorative-use" gypsum, at certainty level $\mathrm{C}$, in limited areas in the northern parts of the study area.

Sand and gravel deposits occur along the valley of the Paria River in the southern part of the study area and on benches in and adjacent to the northern part. The mineral resource potential is moderate for such deposits, at certainty level $\mathrm{C}$.

The energy resource potential for oil and gas is judged to be moderate at certainty level $\mathrm{C}$. Although productive oil and gas formations in the Upper Valley field to the northeast also underlie the study area, and the study area contains structures similar to those in the productive areas, the few test holes that have been drilled are dry or had only minor oil shows in cuttings and have been abandoned.

No hot springs or thermal anomalies are known in the study area. Although the iron-oxide stain and carbonate cement adjacent to fractures suggests fluid flow in fractures, no evidence of high temperatures has been found. Known igneous rocks include intrusive rhyolite about $1 \mathrm{mi}$ south of the study area and extrusive basalts in the Johnson Canyon area 10-15 mi southwest of the area. However, geophysical data give no evidence of volcanic rocks or igneous intrusions that might provide a source of geothermal energy at shallow levels below the study area. There is, therefore, a low resource potential for geothermal energy, at a certainty level of $C$.

Although coal beds are known in the nearby Cockscomb and adjoining Wahweap Wilderness Study Areas, the coalbearing rocks (the Dakota Sandstone and Straight Cliffs Formation) have been eroded from virtually the entire PariaHackberry area and there is no energy resource potential for coal, at certainty level $D$.

\section{INTRODUCTION}

At the request of the U.S. Bureau of Land Management (BLM), the U.S. Geological Survey (USGS) and the U.S. Bureau of Mines (USBM) studied 94,642 acres (148 square miles) of the Paria-Hackberry Wilderness Study Area (UT-040-247) in southern Utah to appraise its identified mineral resources and to assess its mineral resource potential. In addition, the USGS studied 41,180 acres (64 square miles) that are contiguous to the area finally selected for study by the BLM. In this report the entire area is called the "wilderness study area," "study area," or "Paria-Hackberry area," as appropriate. The study 

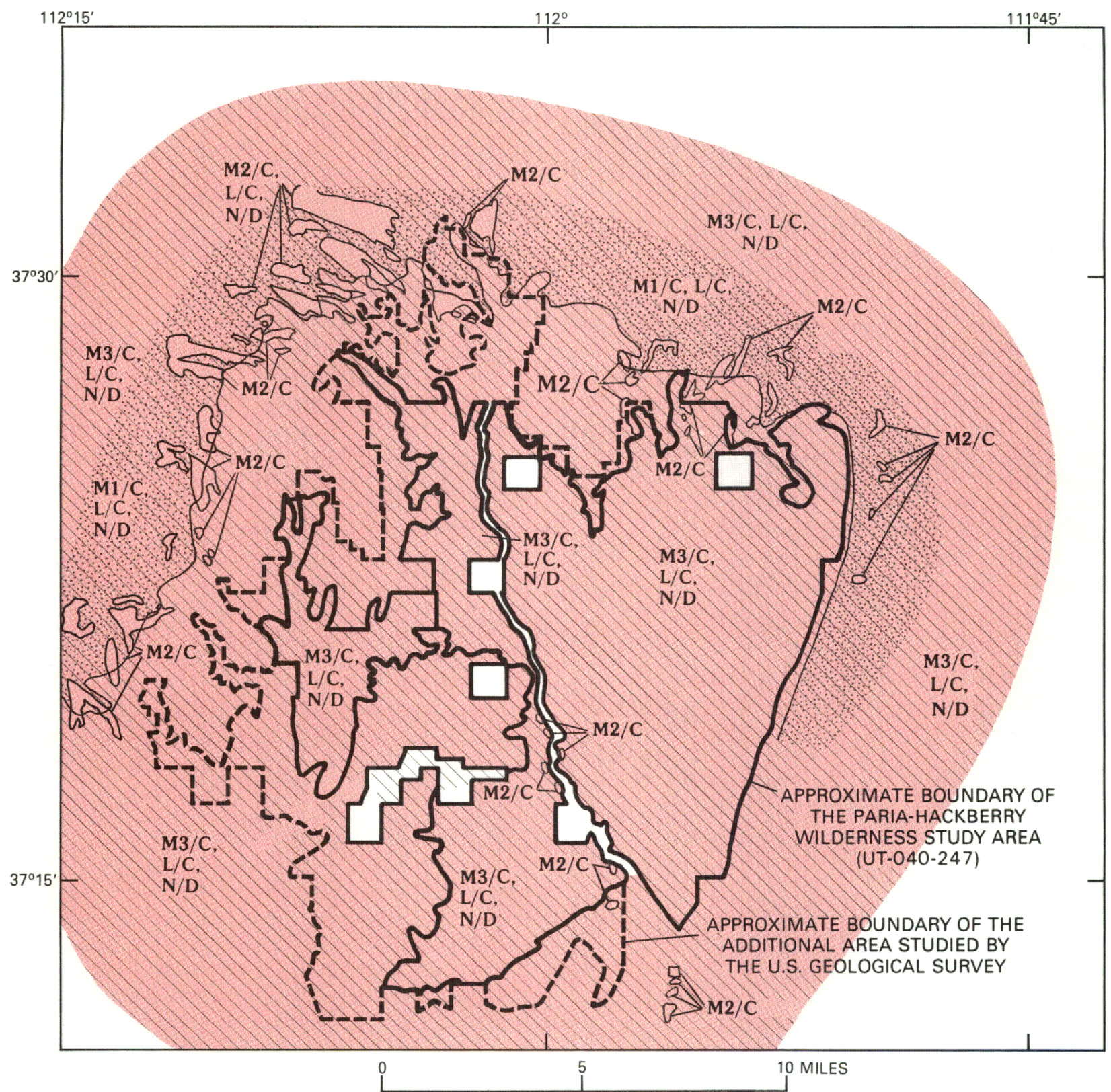

\section{EXPLANATION OF MINERAL RESOURCE POTENTIAL}

\begin{tabular}{|c|c|}
\hline $\mathrm{M} 1 / \mathrm{C}$ & $\begin{array}{l}\text { Geologic terrane having moderate mineral resource potential for gypsum in the Carmel } \\
\text { Formation, at certainty level } \mathrm{C}\end{array}$ \\
\hline $\mathrm{M} 2 / \mathrm{C}$ & $\begin{array}{l}\text { Geologic terrane having moderate mineral resource potential for sand and gravel, at } \\
\text { certainty level } \mathrm{C}\end{array}$ \\
\hline M3/ & $\begin{array}{l}\text { Geologic terrane having moderate mineral resource potential for oil and gas, at certainty } \\
\text { level C-Applies to the entire study area }\end{array}$ \\
\hline $\mathrm{L} / \mathrm{C}$ & $\begin{array}{l}\text { Geologic terrane having low resource potential, at certainty level } \mathrm{C} \text {, for geothermal } \\
\text { resources and for all metals and nonmetals-Applies specifically to gold, uranium, } \\
\text { silver, arsenic, antimony, barium, strontium, zinc, cadmium, mercury, copper, and } \\
\text { manganese. Applies to the entire study area }\end{array}$ \\
\hline $\mathrm{N} / \mathrm{D}$ & $\begin{array}{l}\text { Geologic terrane having no energy research potential for coal, at certainty level D- } \\
\text { Applies to the entire study area } \\
\text { Level of certainty }\end{array}$ \\
\hline $\mathrm{C}$ & $\begin{array}{l}\text { Data indicate geologic environment and give a good indication of level of mineral } \\
\text { resource potential }\end{array}$ \\
\hline D & Available data clearly define the level of resource potential \\
\hline
\end{tabular}

Figure 2. Mineral and energy resource potential of the Paria-Hackberry Wilderness Study Area, Kane County, Utah. 
area is in Kane County, Utah (fig. 1), west of the Cockscomb and Wahweap Wilderness Study Areas (Bell and others, 1990).

The studies, done from 1984 through 1989, included a literature search for information on mines and mineralized areas and an inspection of mining claims and oil and gas lease records. Field work included an inspection of mines and mineralized areas, a geologic reconnaissance, geophysical investigations, and geochemical sampling to acquire data for the assessment of the mineral resource potential and the appraisal of identified mineral resources.

This report presents an evaluation of the mineral endowment (identified resources and mineral resource potential) of the study area and is the product of several separate studies by the U.S. Bureau of Mines and the U.S. Geological Survey. Identified resources are classified according to the system of the U.S. Bureau of Mines and U.S. Geological Survey (1980), which is shown in the Appendix to this report. Identified resources are studied by the USBM. Mineral resource potential is the likelihood of occurrence of undiscovered metals and nonmetals, industrial rocks and minerals, and of undiscovered energy resources (coal, oil, gas, oil shale, and geothermal sources). It is classified according to the system of Goudarzi (1984), which is also shown in the Appendix. Undiscovered resources are evaluated by the USGS.

\section{Location and Geographic Setting}

The wilderness study area is in the High Plateaus section of the Colorado Plateaus physiographic province, west of the Kaiparowits Plateau. Typical canyonlands topography-narrow deep canyons with bordering cliffs separated from mesas of sandstone by terraced benchescharacterizes the study area. In the surrounding area, the benches rise like steps from about $4,000 \mathrm{ft}$ to $7,000 \mathrm{ft}$, but locally the lowest elevation is $4,600 \mathrm{ft}$. Kanab, the county seat, is about $25 \mathrm{mi}$ to the west and Cannonville and Henrieville, in Garfield County, are about 5 mi north of the Paria-Hackberry area. U.S. Highway 89 passes near the southern boundary and provides access to the study area by connecting with unpaved county roads. Along Cottonwood Creek, an unpaved county road separates the PariaHackberry area from the adjacent Wahweap study area and provides access to vehicle trails. The dry bed of the Paria River is usable by field vehicles as a road during much of the year, providing access to the interior of the study area. Water supply is low, seasonal, and erratic. The Paria River, temporary streams in Hackberry Creek and in various canyons, and numerous springs are the principal sources of supply.

\section{Investigations by the U.S. Bureau of Mines}

The U.S. Bureau of Mines investigations for this report were begun in 1984 and continued through 1987. The results of their investigations in the Paria-Hackberry area have been reported on by Brown and Hannigan (1986) and by Thompson (1989). The investigations included a comprehensive literature search for information on mines and mineralized areas, a review of mining claim applications and oil and gas lease records at the Utah State Office of the Bureau of Land Management, and consultation with individuals for information on mines, mineralized areas, and oil and gas exploration. Bureau of Mines personnel spent 36 employee-days in 1984 (Brown and Hannigan, 1986) and 12 days in 1987 (Thompson, 1989) conducting field examinations of mines, prospects, and mineralized areas in and within several miles of the study area.

During the field investigations, 20 rock samples were taken to identify possible gold and uranium occurrences and to evaluate glass-sand sources. Uranium and other metallic elements were sought in 80 stream-sediment samples as indicators of exposed mineralized rocks. Two samples were taken at a gypsum prospect within a mile northeast of the study area. Sixteen rock samples were fire-assayed for gold and silver and spectrographically analyzed for 40 elements; 7 of these samples were analyzed fluorimetrically for uranium. Four rock samples of sandstone were analyzed by inductively coupled plasma analysis (ICP) for silica content and purity. All stream-sediment samples were fire-assayed for gold and silver by ICP, tested for uranium by fluorimetry, and analyzed spectrographically for 40 elements. ICP, fluorimetric, and spectrographic analyses were performed by the Research Center, U.S. Bureau of Mines, Reno, Nevada. Analytical procedures for gypsum followed American Society for Testing and Materials (ASTM) standards and were made by Skyline Laboratories, Wheat Ridge, Colorado. Complete analytical data for all samples are available for public inspection at the U.S. Bureau of Mines, Intermountain Field Operations Center, Building 20, Federal Center, Denver, CO 80225.

\section{Investigations by the U.S. Geological Survey}

Personnel of the USGS made a geologic reconnaissance of the study area in 1986 and 1987 and visited the mines and prospects in the surrounding area. Rocks and stream sediments were sampled for geochemical analysis to provide data for assessment of the mineral resource potential. John Jackson assisted the USGS authors in the field and also with samples and maps in the office. Numerous, earlier wide-ranging studies on coal, oil, and uranium, as well as on metallic and nonmetallic mineral resources, have included parts of the study area. These 
studies described the various rock units and structure. The U.S. Geological Survey extensively studied the land resources, coal, chemical quality of ground and surface water, and other subjects relating to the nearby Kaiparowits coal basin; these studies were published by various authors as U.S. Geological Survey Miscellaneous Investigation Series Maps (1977-1985) numbered I-1033-A through I-1033-L. The present report has relied for much detail on those data. Other principal sources of data include geologic mapping and studies of stratigraphy and structure beginning with Gregory and Moore (1931), Gregory (1948), Hintze (1963), and Hintze and Stokes (1964). Valuable data have also been provided by the geologic map of Kane County, Utah (Doelling and Davis, 1989), which is used as the geologic base for plate 1. Additional data come from a geologic map showing structural features and uranium deposits by Hackman and Wyant (1973). Data on the petroleum potential of the study area have come from Molenaar and Sandburg (1983) and other sources.

\section{APPRAISAL OF IDENTIFIED RESOURCES}

\section{By S. Don Brown, Brian J. Hannigan, and John R. Thompson U.S. Bureau of Mines}

\section{Exploration History}

No mines or patented claims are in the study area, but 149 unpatented claims are within $6 \mathrm{mi}$ of its boundaries (fig. 3). From 1910 to 1913 an attempt was made to hydraulically mine "flour" gold from the Chinle Formation near the now-abandoned Paria townsite close to the southern boundary of the Paria-Hackberry area. Although this early attempt was unsuccessful, another attempt was made a few years later in conjunction with an irrigation project. This attempt also failed and hydraulic mining was abandoned (Gregory and Moore, 1931, p. 148).

About 20 square miles of the Paria-Hackberry Wilderness Study Area is leased for oil and gas exploration (fig. 3) and there has been drilling inside the study area. Eight holes were drilled between 1929 and 1975 in and near the study area (pl. 1), and oil shows or stains were present in four of them. Hole depths ranged from 2,085 to 7,252 ft. Oil shows were reported from the Timpoweap Member of the Moenkopi Formation, from the Cedar Mesa Sandstone Member of the Cutler Formation, from the Kaibab Limestone, and from the Toroweap Formation (C.J. Brandt in Doelling and Davis, 1989, p. 116-117).

\section{Metals and Nonmetals}

Although some of the rock units in the study area are favorable hosts for uranium, and occurrences of gold, copper, lead, manganese, and gypsum are found nearby, no identified resources of these commodities are present in the study area. Evidence of minor prospecting activity for copper, lead, manganese, and uranium was found outside the study area during the field investigation, but evidence of mining activity was not seen inside the area.

The "flour" gold occurrence at the old Paria townsite was investigated, but four samples of weathered, clayey shale or mudstone taken from the Chinle Formation did not contain detectable gold. Stream-sediment samples, taken to determine if gold was present at other nearby locations, indicate that gold is not present in concentrations that are economically minable using modern technology. This investigation did not reveal an identified resource of gold in the study area.

At a copper and lead occurrence about $1 \mathrm{mi}$ north of the study area (pl. 1), 90- and 100-ft-deep shafts (shown by one symbol on plate 1) were sunk into the Carmel Formation, but rotten timbers at the collars of the shafts prevented inspection and sampling. Mineralized rock on the dumps was a buff sandstone with nodules and blebs containing abundant malachite, hematite, and some manganese. A select sample by Brown and Hannigan (1986) from a small stockpile contained 6.3 percent copper and 9.7 percent lead. Nearby similar nodules, as much as $1 \mathrm{ft}$ in diameter, were found weathering out of the same sandstone unit of the Carmel Formation. A sample of a nodule (Brown and Hannigan, 1986) contained 10.4 percent copper and 1.1 percent lead. None of these nodules were found in the study area (but see later section on geochemical studies).

At the King mine, about $1 \mathrm{mi}$ south of the area studied by the USGS (pl. 1), a 70-ft long adit was driven into intrusive rhyolite; a bulldozer pit exposes more rhyolite. Manganese occurs in the rhyolite as psilomelane in nodules, stringers, and coatings in a 5-ft-thick zone. Samples from the mine area contained as much as 9.6 percent manganese. Manganese grades must exceed 30 percent in order to be considered minable. No other intrusive rocks nor evidence of manganese mineralization were found, and no identified resource of manganese can be assigned to the study area.

Some rocks of the Paria-Hackberry area are suitable for ordinary, colored container glass, roadfill, or construction purposes, and a thick bed of "decorative-use" gypsum is just outside the area.

High silica rock in the Navajo Sandstone was examined as a possible source of glass sand. Four samples of the Navajo Sandstone taken in and near the PariaHackberry area contained from 93.7 to 96.7 percent silica $\left(\mathrm{SiO}_{2}\right)$ and from 0.21 to 0.33 percent iron $\left(\mathrm{Fe}_{2} \mathrm{O}_{3}\right)$ (Brown and Hannigan, 1986). Analyses indicate that the Navajo Sandstone could be used in the manufacture of ordinary, 


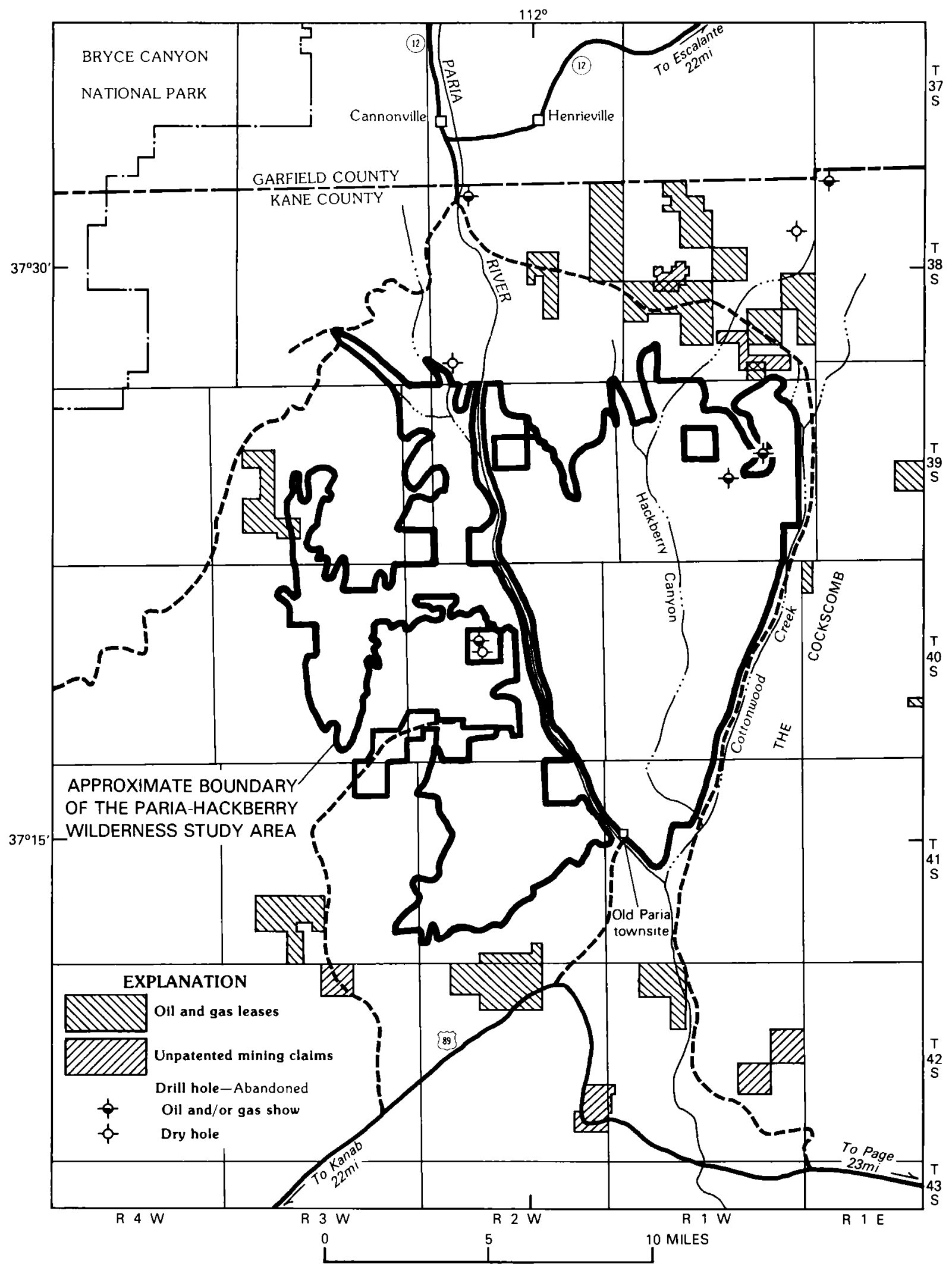

Figure 3. Oil and gas leases (data from U.S. Bureau of Mines as of March 1989), unpatented mining claims (data from U.S. Bureau of Mines as of January 1990), and oil and (or) gas drill holes in the Paria-Hackberry Wilderness Study Area and vicinity, Kane County, Utah (modified from Thompson, 1989). Claims in R. 1-3 W., T. 42 S. and all drill holes are located only by section. 
colored-container glass (V.V. Tepordei, Industrial Mineral Specialist, Bureau of Mines, Washington, D.C., oral commun., March 1985). Abundant stone for these purposes is available closer to population centers and markets.

Outside the study area (one-half mile to the north), along upper Cottonwood Creek, a 25-ft-thick gypsum bed is interstratified with limestone in the Carmel Formation. This massive, white gypsum bed is quarried and sold in small amounts on a sporadic basis as decorative stone (Pete Kilbourne, Bureau of Land Management, Kanab, Utah, oral commun., January 1986). The softness of the stone precludes its use except as a facing stone, but it shows beautiful layering when polished. Two samples of the gypsum (analyzed to ASTM standards) contained 87.9 and 92.6 percent gypsum and 0.92 and 1.05 percent anhydrite, respectively (Thompson, 1989). Although gypsum may be present below the surface, there is no identified resource of gypsum in the study area.

\section{Energy Sources}

The Chinle Formation is a favorable host rock for uranium deposits in the Colorado Plateau, but in the vicinity of the study area it lacks uranium. Two prospects were found in the Chinle about one-half mile south of the area studied by the USGS (pl. 1) near Kitchen Corral Wash, and prospect pits were also found near the old Paria townsite. The sandstone at the prospects in Kitchen Corral Wash had a scintillometer reading of $40 \mathrm{cps}$ (counts per second), which is two times background. Three samples of the most radioactive material present at the prospects contained 2.5 , 2.3, and $3.2 \mathrm{ppm}$ (parts per million) uranium, respectively. The average concentration of uranium in sandstone and siltstone ranges from 0.45 to $3.2 \mathrm{ppm}$ (Levinson, 1980, p. 885 ). The analytical results from the prospect samples, therefore, are within the range expected for average uranium content of sandstone and siltstone. The results are significantly less than the 1990 uranium ore grade of about 0.25 percent $\mathrm{U}_{3} \mathrm{O}_{8}$.

Four samples of clayey material were taken from prospect pits in the Chinle Formation near the old Paria townsite. Scintillometer readings in this area were also about twice background, and the samples contained from 2.6 to $6.0 \mathrm{ppm}$ uranium. Stream-sediment samples were also taken in the vicinity and analyzed, but the uranium content was low. The concentration of uranium in the rock and stream-sediment samples near these prospects does not suggest the presence of an identified uranium resource.

Most of the oil and gas production in south-central Utah has been from structural traps. The Upper Valley oil field, $16 \mathrm{mi}$ northeast of the study area, is on the flank of the Kaibab anticline. Discovered in 1964, the Upper Valley oil field has produced more than 19 million barrels of oil from the Kaibab Limestone, making it the fifth-largest producer in Utah. The study area region is stratigraphically and structurally similar to the Upper Valley oil field, according to Oakes and others (1981) and to Doelling (1975, p. 91-97).

Oil shows and staining in the Paleozoic rocks have been reported from eight drill holes in or near the study area (pl. 1). In 1966, Amoco Oil Company drilled two test holes for oil and gas in sec. 16, T. 40 S., R. 2 W. They lost one hole, but reported oil shows in cuttings from the Toroweap Formation at a depth of 2,626-2,790 ft (C.J. Brandt in Doelling and Davis, 1989, p. 116-117). The site was abandoned shortly after completion of the hole. In 1930 and 1970 , two holes were drilled in and near the northeast part of the study area (secs. 14 and 22, T. 39 S., R. 1 W.). Oil shows were reported in the Timpoweap Member of the Moenkopi Formation, in the Kaibab Limestone, and in the Toroweap Formation. In 1973, Amerada Hess Oil Company drilled two holes northeast of the study area (sec. 6, T. 38 S., R. 1 E., and sec. 12, T. 38 S., R. 1 W.); neither contained shows of oil or gas. In 1970 and 1975, two holes were drilled, one next to and one near the northwest part of the study area. The northwest hole contained oil shows in the Cedar Mesa Sandstone Member of the Cutler Formation, the other had no shows of oil or gas (C.J. Brandt in Doelling and Davis, 1989, p. 116-117).

\section{ASSESSMENT OF POTENTIAL FOR UNDISCOVERED RESOURCES}

\section{By Henry Bell III, Alfred L. Bush, Robert L. Turner, and John W. Cady U.S. Geological Survey}

\section{Geologic Setting}

The Paria-Hackberry Wilderness Study Area is underlain by gently folded but generally flat-lying sedimentary strata (pl. 1). Older formations ranging from the Permian Kaibab Formation to Jurassic-age sandstones in the Carmel Formation crop out west of the East Kaibab monocline. Younger formations ranging from the Jurassic Entrada Sandstone to the Cretaceous Kaiparowits Formation are mostly to the east of the monocline. The Paunsaugunt fault, which has a large displacement in Garfield County to the north, is close to the western boundary of the study area. Windblown sand, alluvial sand and gravel, and talus deposits are widespread on benches, along the river and canyon floors, and along the base of cliffs. They are Quaternary in age, as is a small lava flow in a canyon about $7 \mathrm{mi}$ west of the study area. Widespread lavas and volcanic deposits of Tertiary age occur to the north but do not extend south into the study area; a small mass of intrusive rhyolite (not shown on pl. 1) occurs about one-half mile south of the study area. 


\section{Summary Description of Rock Units}

Limestone in the Kaibab Formation of Permian age is the oldest outcropping rock in the study area. Mudstones and sandstones of the Triassic Moenkopi Formation underlie a wide bench through which windows have been eroded, exposing the Kaibab south of the Paria-Hackberry area and west of the Cockscomb along the East Kaibab monocline. Rocks of the Triassic Chinle Formation unconformably overlie the Moenkopi. They are variegated clayrich rocks with local sandstone and conglomerate beds, commonly in the form of stream channel deposits, near the base. In some parts of Colorado and Utah these paleostream deposits are incised into the underlying formation. Above the Chinle Formation are massive cliff-forming sandstones of the reddish Moenave Formation, Kayenta Formation, and clean white sandstones of the Navajo Sandstone. Those rocks are probably Jurassic in age (Peterson and Pipiringos, 1979). They are the rocks into which the Paria River Canyon, Hackberry Canyon, and Bull Valley Gorge are eroded, forming cliffs of $600-1,000 \mathrm{ft}$ that expose the entire thickness of the formations. Cliffs of these rocks surround No Mans Mesa and are prominent as the White Cliffs, a conspicuous physiographic feature in southern Utah. They are the principal outcropping rocks in the Paria-Hackberry Wilderness Study Area.

Along the East Kaibab monocline, the steeply eastdipping rocks range from the Carmel Formation in the study area, to the Henrieville (usage of Doelling and Davis, 1989) and the Entrada Formations, which are Jurassic in age, to the Cretaceous Dakota Sandstone and overlying Tropic Shale, just east of the study area; all these rocks are much fractured and deformed by faulting. The sandstones form narrow hogbacks and cockscomblike outcrops, characteristic of the nearby Cockscomb Wilderness Study Area, separated by more easily eroded mudstones and soft sandstones. The Carmel Formation is a unit of marine red beds, with sandstone, limestone, and gypsum beds. Some of the sandstones form cliffs and are particularly conspicuous along the northern part of the Cockscomb, along Cottonwood Creek, and to the north and west in the Paria-Hackberry area where mudstone, siltstone, slabby limestone, and gypsum locally form slopes (as much as 11 ft thick). Cliff-forming sandstones and clay-rich sandstones in the upper part of the Carmel and in the Entrada also occur north of the Paria-Hackberry study area where Gregory (1951, p. 57) reported the occurrence of copper in the upper part of sandstone beds. On Kodachrome Flats nearby, local, small, distinctively shaped, nearly vertical structures with distorted and brecciated bedding may be chimneys or breccia pipes. They may be collapse features resulting from solution in the subsurface of rocks, such as anhydrite, gypsum, or limestone, by ground water circulating in the Carmel Formation or Entrada Sandstone. They are similar, in many respects, to the copper-uranium-bearing breccia pipes of the Kaibab and Coconino Plateaus in northern Arizona. Cliff-forming rocks of similar appearance in the Carmel Formation, Entrada Sandstone, and Henrieville Formation were eroded during the Jurassic Period resulting in a widespread unconformity on which the Cretaceous Dakota Sandstone was deposited.

Quaternary unconsolidated sands and sandy clays in the alluvium along canyon and river bottoms are the youngest deposits in the study area. Low river terraces along the Paria River underlain by thick alluvium were the sites for now-abandoned farming villages. Along the floor of some canyons in the study area, cobbles and boulders of quartzite and volcanic rocks derived from sources to the north occur in alluvium and these have formed gravel deposits on terraces along Paria River and the broad lower reaches of some canyons. Locally thick windblown sand deposits occur. Blocks of sandstone and other rocks fallen from cliffs, as well as landslides, are common and widespread near the cliffs.

\section{Structure}

The East Kaibab monocline and the Paunsaugunt fault are major north-trending structures in southern Utah. The East Kaibab monocline separates strata on the west from strata as much as $7,000 \mathrm{ft}$ stratigraphically higher on the east. Within and just east of the study area, rocks ranging in age from Permian to Late Cretaceous have been folded in the monocline. The width of the belt of steeply dipping rocks between outcrops of the Kaibab Limestone on the west and nearly flat-lying rocks in the Dakota Sandstone on the east is only about $2 \mathrm{mi}$ where the monocline is within the Cockscomb Wilderness Study Area. To the north, however, the width increases and the dip is less steep.

The Paunsaugunt fault, which bounds the Paunsaugunt Plateau on the east, is outside but near the west edge of the study area. To the north in Garfield County it has a large displacement; its throw separates beds by $2,000 \mathrm{ft}$. West of the study area, however, where the fault extends southward, it is defined by a zone of faulting and fracturing and only minor offset of beds. Along the East Kaibab monocline in Cottonwood Canyon and south of the Paria River, numerous closely spaced faults, trending both along the strike of beds and to the northeast, fragment and offset steeply dipping rocks. Other faults cut rocks in the monocline and trend northwest. Some northwest-trending faults extend along the Paria River and near Hackberry Canyon. These faults may be splays of the Paunsaugunt fault or they may be related to the zone of faulting west of the study area. The displacement of strata appears to be minor along the Paria River and Hackberry Canyon. Some of the faults and fractures have served as conduits for fluids. Local ironoxide staining, calcium-carbonate cement in rocks adjacent to fractures, and silica-cemented sandstone dikes (Sargent 
and Philpott, 1985) indicate that fluids of various compositions have been present.

Between the East Kaibab monocline and the Paunsaugunt fault is the broad Kaibab anticline plunging at a low angle northward. Both to the east and the west of the East Kaibab monocline, sinuous north- or northeast-trending shallow folds are superimposed on the larger structure.

Several widespread unconformities, formed at various times during Permian to Cretaceous deformation, truncate the folded rocks. The Dakota Sandstone was deposited on one such erosion surface with the result that rocks such as the Summerville Formation and stratigraphic equivalents beneath the Dakota Formation east of the monocline are thin or missing west of the monoclines.

\section{Geochemical Studies}

A reconnaissance geochemical survey was conducted in the study area in 1985 and 1988 to aid in assessment of the mineral resource potential. Minus-80-mesh stream sediments, nonmagnetic heavy-mineral concentrates derived from stream sediments, and rocks were selected as appropriate sample media. The sediment and concentrate samples were collected at 142 sites, and 60 rock samples were collected at 50 sites.

Chemical analysis of stream sediments and nonmagnetic concentrates helps target or identify drainage basins in which alluvium contains unusually high concentrations of elements that possibly may be related to mineralized rock. Each sample was composited from several localities along a channel length of about $50 \mathrm{ft}$. The stream sediments were sieved through an 80-mesh screen and pulverized to a fine powder before analysis. The heavy-mineral concentrates were sieved through a 10-mesh screen and then panned until most of the quartz, feldspar, clay-size material, and organic matter were removed. The remaining light minerals were separated from the heavy minerals with a heavy liquid (bromoform, specific gravity 2.8 ). The magnetite and ilmenite were removed with an electromagnet from the material of specific gravity greater than 2.8 . The remainder of each sample was then separated into magnetic and nonmagnetic fractions using an electromagnet. The concentrates were ground to a fine powder, and rock samples were crushed and pulverized before analysis.

Stream sediments and corresponding concentrates were collected from active alluvium in the stream channel in small streams and below the junction of two streams whose catchment basins ranged in size from fractions of a square mile to several square miles. Stream sediments provide a representative chemical and lithologic composite sample of rocks exposed in the upstream drainage basin. Elements associated with useful mineral deposits may be detected in the sample by chemical analysis, but the values obtained commonly are small. For this reason, a second sample, the heavy-mineral concentrate, is collected in combination with the stream sediment to test the transported heavy-mineral components of alluvium for minerals that result from ore-forming processes. The heavy-mineral concentrate represents a concentration of ore-forming and ore-related minerals (if ore mineralization has occurred in the source area) that permits determination of some elements that are not easily detected in bulk stream sediments. With most of the rock-forming silicates, clays, and organic material removed from the concentrate, values obtained by chemical analyses may be enhanced to the point that anomalous samples are easily recognized and ore minerals identified.

Rock samples were collected from mineralized and unmineralized outcrop and stream float. Samples that appeared fresh and unaltered were collected to provide information on background metal concentrations. Altered or mineralized samples were collected to determine the suite of elements associated with the observed effects of alteration or mineralization. In addition, samples of iron-oxide stained rocks and calcium-carbonate cemented rock near fractures and faults were collected at various places in the study area, particularly near mineral prospects, to test for possibly anomalous metal concentrations.

All samples were analyzed for 31 elements by a six-step, direct-current arc, semiquantitative, emissionspectrographic method (Grimes and Marranzino, 1968; Crock and others, 1983, 1987). In addition, the rocks and stream sediments were analyzed by more sensitive and precise techniques for arsenic, bismuth, cadmium, antimony, and zinc (O'Leary and Viets, 1986); for gold (Thompson and others, 1968); and for mercury (Koirtyohann and Khalil, 1976). Analyses for uranium were by a delayed neutron-activation technique (McKown and Millard, 1987). A complete listing of the analytical results and a concise description of the sampling and analytical techniques are given in Hageman and others (1990).

The results of the analysis of the minus-80-mesh stream sediments delineated a zone in the south-southeast part of the study area (area A, pl. 1) that has anomalous values for cadmium (0.3-0.5 ppm (parts per million)) and barium (1,000-2,000 ppm). Another zone in the northwest part (part of area $\mathrm{C}, \mathrm{pl}$. 1) has anomalous values for arsenic (8-16 ppm). One site in the east-central part has anomalous mercury $(0.26 \mathrm{ppm})$.

The results of the analysis of the nonmagnetic fraction of the heavy-mineral concentrates delineated two zones of high values (pl. 1). The first is in the southsoutheast part of the study area (area A, pl. 1) with high strontium (greater than $10,000 \mathrm{ppm}$ ), and the second is in the north-central part (part of area C, pl. 1) with high values for arsenic (200-1,000 ppm) and silver (as much as $5 \mathrm{ppm}$ ). There is one site in the northwest comer of the study area with high strontium (greater than $5,000 \mathrm{ppm}$ ) and one site in the south-central part with silver (5 ppm) and arsenic (1,000 ppm). 
The results of the analysis of the rocks identified three zones with anomalous values. The first is in the southsoutheast part (area A, pl. 1) of the study area with values for arsenic (15-48 ppm), cadmium (1.8-14 ppm), mercury (0.12-0.22 ppm), antimony (6-7 ppm), gold (0.1 ppm) and zinc (as much as $710 \mathrm{ppm}$ ). The second zone is in the east-central part (area B, pl. 1) and contains arsenic (24-80 ppm), cadmium (1.8-2 ppm), and zinc (100-410 ppm). The third zone is in the northwest part (area C, pl. 1) and contains arsenic (14-310 ppm), antimony (as much as 7 ppm), cadmium (3.3-4 ppm), and zinc (410-700 ppm). There are three scattered sites in the northeast part of the study area with anomalous values for arsenic (11-410 ppm), antimony (as much as $100 \mathrm{ppm}$ ), mercury (as much as 0.38 ppm), copper (as much as $200 \mathrm{ppm}$ ), and lead (as much as $500 \mathrm{ppm}$ ).

The barium and cadmium values from the stream sediments and the strontium values from the nonmagnetic fraction also fall in zone $A$ in the south-southeast part of the study area. This anomalous zone is generally in and around the Chinle Formation of Triassic age and might result from the manganese nodules weathering out of some of these rocks in the zone.

The anomalous values for silver, arsenic, antimony, gold, mercury, cadmium, and zinc from the rocks and stream sediments and the high values for silver and arsenic from the nonmagnetic fraction are at sites scattered throughout the study area and show no association with specific rock units nor any discernible pattern. There does not appear to be an association of these anomalous sites with any one geologic unit. The possibility exists that the occurrences may have a hydrothermal origin.

The only visibly mineralized zone in the study area is north-northwest of the now-abandoned townsite of Paria where manganese nodules are weathering out of the Chinle Formation. The generally scattered distribution of the sites with anomalous or high values might be attributed to supergene redistribution of the metals from the Chinle Formation into the overlying units as iron- and manganeseoxide coatings in faults and fractures.

\section{Geophysics}

Gravity and aeromagnetic data, obtained for additional information about the study area, provide information about rock units in the upper crust that have contrasting densities and contrasting magnetic properties. The magnetic properties depend mainly on the abundance of magnetite. The contrasts primarily reflect lithologic variations in the Precambrian basement.

Gravity data (Viki Bankey, written commun., 1986) for the Bouguer gravity anomaly map of Utah (Cook and others, 1989) were supplemented by additional local data collected for the purposes of this report (McCafferty and Cady, 1987). Bouguer and terrain corrections were made using a reduction density of $2.30 \mathrm{~g} / \mathrm{cm}^{3}$ (gram per cubic centimeter), which minimized the correlation between local negative gravity anomalies and high topography on maps made using the standard Bouguer reduction density of 2.67 $\mathrm{g} / \mathrm{cm}^{3}$. Aeromagnetic surveys were flown along flight lines about $3 \mathrm{mi}$ apart and $400 \mathrm{ft}$ (nominal) above the ground. These surveys provided magnetic data in digital tape form (Geodata International, Inc., 1980; Geo-Life, Inc., 1980) suitable for study.

Neither the gravity nor the aeromagnetic surveys were designed primarily for mineral resource or hydrocarbon investigations. The aeromagnetic survey (flown along flight lines $3 \mathrm{mi}$ apart) resulted in a lack of interline detail, and the gridding and contouring process preserved only the long-wavelength components. Gravity information originally available from closely spaced gravity stations also was lost in the gridding and contouring process. Hence the data cannot resolve small features.

The gravity map (fig. 4) is dominated by anomaly GH1, a broad north- northeast-trending high that has Bouguer anomaly values 10-20 milligals higher than the broad gravity low, anomalies GLa-GLd. Gravity stations are too sparse to allow the depth to the source of anomaly GH1 to be calculated, but it is probably as deep as the sources of magnetic high anomaly MH1, 4-6 mi. Several shorter wavelength gravity highs, with amplitudes of 5-10 milligals, are scattered over the eastern part of the map area and are probably caused by shallower sources.

The aeromagnetic map (fig. 5) shows a northnortheast-trending band of magnetic highs and lows, defined by the long-wavelength components. To identify short-wavelength anomalies indicating buried volcanic rocks, near-surface intrusions, or clinker, the magnetic data in profile form recorded along the flight lines (Bendix Field Engineering Corporation, 1983a,b) were inspected. No such features were found in the study area. In the west, the depth to the magnetic sources, estimated from the width of the zones of steepest gradient bounding the highs, is 4-6 mi. To the east of low anomaly MLa (fig. 5) are shorter wavelength magnetic highs and lows that indicate magnetic sources as shallow as $2 \mathrm{mi}$.

The magnetic and gravity maps show important features in common: anomalies trend north-northeast; longwavelength, correlative highs occur in the west (MH1 and GH1) (the Paria-Hackberry study area is in the central part of the map); long-wavelength, correlative lows occur in the central and northeastern part of the map (MLa and GLaGLd); short-wavelength, poorly correlative highs and lows occur in the east and overlap the center on the gravity map.

The sources of the magnetic highs must be in the crystalline basement, for the Phanerozoic sedimentary cover is nonmagnetic. Similarly, the dense sources of most of the gravity highs are probably in the basement as well. In the western part of the map area (figs. 4 and 5), magnetic and gravity high anomalies $\mathrm{MH} 1$ and $\mathrm{GH} 1$ correlate with a 


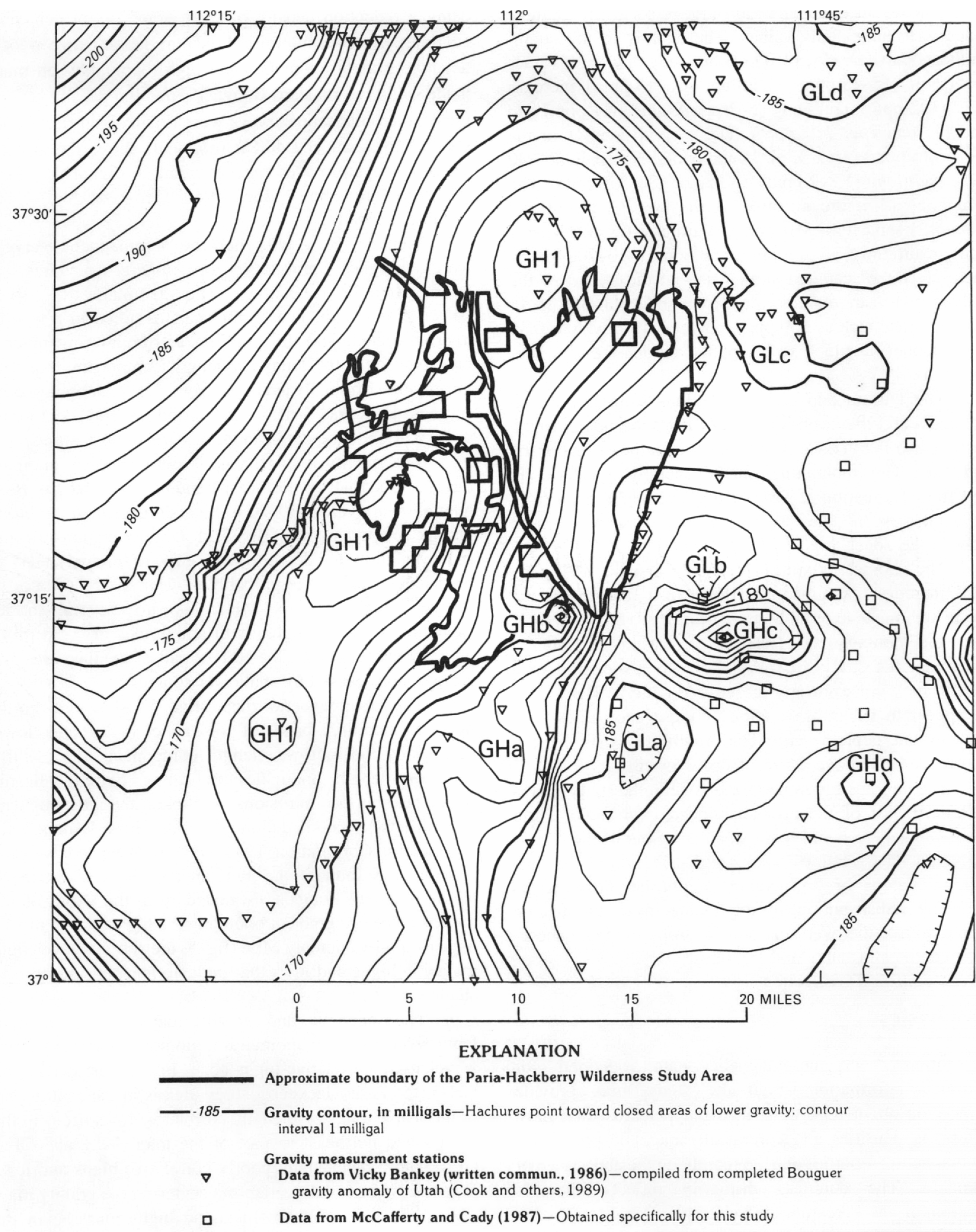

Figure 4. Complete Bouguer gravity anomaly map of the Paria-Hackberry Wilderness Study Area and vicinity, Kane County, Utah. Bouguer reduction density 2.30 grams per cubic centimeter. Gravity high $\mathrm{GH} 1$ correlates with magnetic high $\mathrm{MH} 1$ on figure 5. Other gravity highs (GHa-GHd) and lows (GLa-GLd) do not correlate with magnetic anomalies. 


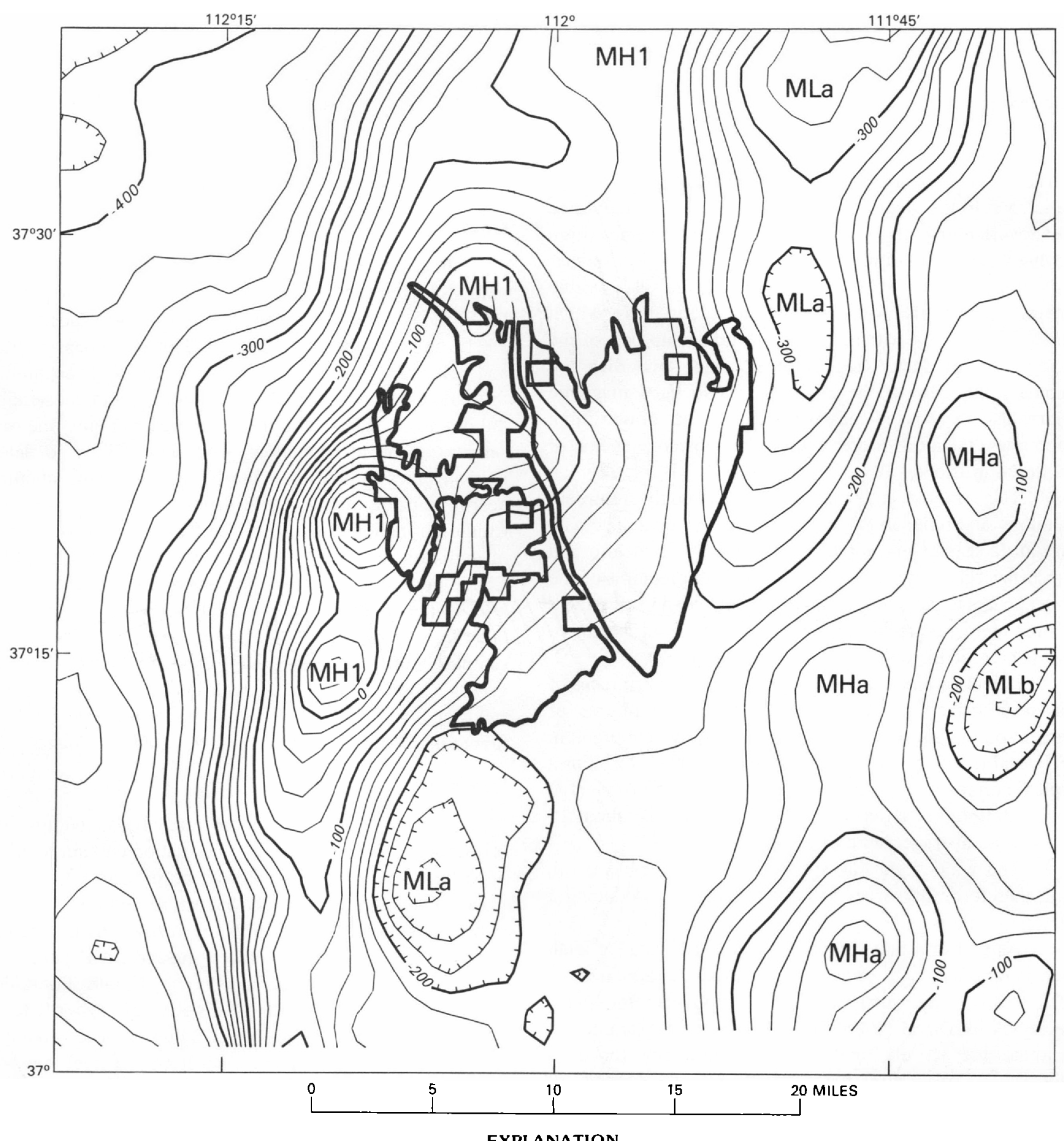

EXPLANATION

Approximate boundary of the Paria-Hackberry Wilderness Study Area

-100 - Aeromagnetic contour showing residual magnetic intensity-Hachures point toward closed areas of lower magnetic intensity; contour interval 20 nanoteslas

Figure 5. Residual total field aeromagnetic map of the Paria-Hackberry Wilderness Study Area and vicinity, Kane County, Utah. Flight lines (not shown) are east-west, 400 feet (nominal) above ground, and about 3 miles apart. Magnetic high MH1 correlates with gravity high $\mathrm{GH} 1$ on figure 4. Magnetic high $\mathrm{MHa}$ and lows MLa and MLb do not correlate with gravity anomalies.

broad anticline in the surface rocks (pl. 1 and Hackman and Wyant, 1973). The magnetic and gravity highs are probably caused by an uplifted block of dense, magnetic basement bounded by the Paunsaugunt fault on the west and the East Kaibab monocline on the east. Thick sedimentary rocks east of the monocline cause magnetic low anomaly MLa and 
gravity low anomalies GLa-GLd. In the eastern part of the map area, where there is little correlation between mapped geology (pl. 1 and Hackman and Wyant, 1973) and geophysical anomalies, the anomalies are probably caused by lithologic variations within a fairly shallow basement block.

A cluster of short-wavelength, gravity high anomalies (GHa-GHd) probably delineates a belt of dense, nonmagnetic rock in the shallow subsurface east of the study area and overlapping its southeastern corner. Gravity high anomaly GHc is diminished slightly when a Bouguer reduction density of $2.67 \mathrm{~g} / \mathrm{cm}^{3}$ is used. A possible interpretation is that some of the anomalous mass, which has a density greater than $2.3 \mathrm{~g} / \mathrm{cm}^{3}$, makes up part of the topography of Jack Riggs Bench, which underlies the anomaly. In view of the absence of associated magnetic anomalies, there is no reason to suspect that gravity high anomalies GHa-GHd are caused by volcanic rocks or shallow intrusions.

The gravity and magnetic data mainly represent lithology and relief in the Precambrian basement. The data provide a framework for understanding the structure and subsurface geology in the study area. Interpretation of the data appears to have little or no direct bearing on assessment of the mineral resource potential, but contributes to assessment of the energy resource potential.

Aerial gamma-ray spectroscopy provides estimates of the near-surface $(0-$ to $50-\mathrm{cm}$-depth) concentrations of percent potassium $(\mathrm{K})$, parts per million equivalent uranium (eU), and parts per million equivalent thorium (eTh). For a typical aerial survey, each measurement represents average concentrations for a surface area on the order of about 15 acres to an average depth of about $1 \mathrm{ft}$.

The wide flight-line spacing of the survey is $3 \mathrm{mi}$, and, therefore, the survey is only suitable for producing a regional-scale map.

As part of a State mapping project, the data for Utah were compiled and processed to produce a series of $1: 1,000,000$ maps that includes composite-color maps described by Duval (1983). These maps were examined to estimate the $\mathrm{K}$, eU, and eTh concentrations for each wilderness area, and the occurrence or absence of anomalous radioelement concentrations were noted. An anomaly requires that the element concentration as well as its ratios to the other two elements all be high values in the context of the map.

The Paria-Hackberry Wilderness Study Area has overall low radioactivity; concentrations are 0.4-1.6 percent $\mathrm{K}, 0.5-1.5 \mathrm{ppm}$ eU, and 1-4 ppm eTh (J.S. Duval, written commun., 1990). There are no radiometric anomalies within or near the study area.

\section{Mineral Resource Potential}

An attempt was made to mine gold by hydraulic methods at the old Paria townsite, just outside the Paria-
Hackberry Wilderness Study Area, and there is evidence of prospecting efforts for uranium, copper, and manganese within the study area. Sand and gravel and gypsum have a moderate mineral resource potential, oil and gas has a moderate energy resource potential; all other mineral commodities and energy sources are rated as low, except for coal, for which there is no potential.

\section{Gold}

In addition to the occurrence at old Paria townsite, gold also occurs in the Chinle Formation in nearby parts of Utah and Arizona (Lawson, 1913; Gregory and Moore, 1931), although the very fine particle size (Phoenix, 1963) and clay-rich matrix make detection and separation difficult. Geochemical analyses of stream-sediment samples did not detect any gold in the study area and only one rock sample contained anomalous gold. This failure to detect gold in other samples and the failure of mining attempts nearby indicate that any gold deposits associated with the Chinle Formation are scattered in this area. The likelihood of undiscovered low- or higher grade gold deposits in the Chinle Formation is, therefore, judged low in the study area at certainty level $\mathrm{C}$. The potential for gold deposits in all other formations is also low at certainty level C. None of the samples collected contained detectable gold, and the geologic setting in which the widespread formations of sandstone and shale were deposited is not known to be favorable for the occurrence of large gold deposits.

\section{Uranium}

Sandstone and conglomerate beds within the predominantly clay-rich Chinle Formation contain uranium deposits (locally copper- and vanadium-bearing) at many places in Colorado and Utah. Sandstone and conglomerate rich in carbonaceous plant remains in paleostream-channel deposits are especially favorable sites for, and guides to, undiscovered uranium deposits. The Chinle Formation crops out in the canyon of the Paria River, in lower Kitchen Corral Wash, across a wide bench between these two areas, and in Hackberry Canyon. Sandstone channel deposits occur in these areas, but no samples with high values for uranium were found during the investigation. No areas of anomalously high radioactivity have been recognized by Duval (1983) in data from airborne surveys. In addition, the high ratio of sandstone and conglomerate to mudstone in these areas is not characteristic of ore-bearing rocks in the Chinle Formation elsewhere in Colorado and Utah (Dubyk and Young, 1978). For these reasons the Chinle Formation in the study area is considered to have only a low mineral resource potential for small deposits of uranium-bearing minerals, with a certainty level of $\mathrm{C}$.

\section{Other Metals}

Geochemical surveys using stream sediments have shown a zone in the southwest part of the study area where 
a number of samples yield anomalous chemical values for the following elements: barium, cadmium, and strontium. The source of the cadmium may be manganese nodules weathering from the Chinle Formation. A significant mineral deposit is not indicated, however. The values for barium and strontium are those expected from sedimentary rocks deposited in a marginal marine basin. Most of the geochemical samples, however, have only values commonly found in chemical analyses of similar materials. The few anomalous chemical values are low and from widely spaced sampling sites; in the absence of other factors, no more than a low level of mineral resource potential for these metals, at certainty level $\mathrm{C}$, can be assessed. In this setting the rocks commonly have carbonate cement containing traces of barium or other barium minerals, and layers and veins of gypsum with traces of strontium. A low resource potential for large-tonnage deposits of barium or strontium, with a certainty level of $\mathrm{C}$, is indicated; the rocks do not have the characteristics of barium- or strontium-bearing rocks deposited in a deepwater marine environment where large tonnage deposits might be expected.

Metal-bearing vein deposits might be expected where fluids have moved on fractures that penetrate gypsum beds, impure limestones, and red sandstone containing traces of copper minerals, and such conditions do occur near the study area. However, samples of iron-oxide-stained rock and calcite-cemented rock (showing the effects of circulating fluids) collected near fractures and fault zones along the Paria River and Hackberry Canyon were found to have only slightly high values for one or more of the pathfinder elements arsenic, antimony, copper, manganese, and zinc. No high values were found for any of these elements, and the concentrations are considered neither anomalous nor necessarily indicative of ore-forming environments. The mineral resource potential for metalbearing vein deposits in the study area is low, at certainty level B. Throughout most of the study area, a few widely scattered samples of stream sediments and concentrates show anomalously high values for arsenic, silver, or mercury. The likelihood of deposits enriched in any of these elements is, therefore, considered to be low, and the overall mineral resource potential for arsenic, antimony, silver, copper, manganese, mercury, and zinc is low, at certainty level $\mathrm{C}$, throughout the study area.

\section{Gypsum}

Gypsum, in occurrences similar to that outside the study area (described earlier in "Appraisal of identified resources"), is possible in the Carmel Formation in limited areas in the northern part of the study area. The mineral resource potential for small gypsum deposits, suitable for use as decorative stone, is rated as moderate, at certainty level $\mathrm{C}$ (see fig. 2, and pl. 1).

\section{Sand and Gravel}

Small deposits of sand and gravel lie in the alluvium along the Paria River in the southern part of the study area. Larger deposits lie on benches supported by the Carmel Formation and the Entrada Sandstone just outside the northern and western parts of the study area and extend into it in a few places. The mineral resource potential for small occurrences of sand and gravel is moderate in those parts of the study area, at certainty level $\mathrm{C}$.

\section{Energy Resource Potential}

\section{Oil and Gas}

The likelihood of oil and gas accumulations within the study area is low to moderate, because rock units from which oil and gas has been produced underlie the study areas, and structures are present similar to those in the producing Upper Valley field. Widespread unconformities truncating the gently folded rocks in the study area may have created sites of possible hydrocarbon accumulation along the unconformities. Although some test holes have been drilled without success (a hole with oil shows and stains in the Kaibab Limestone near the Paria River just outside the study area, and dry holes on the Butler Valley and the Tommy Valley anticlines), the geologic and structural conditions within the study areas are permissive of oil and gas accumulation. The area has been appraised as having "low" potential by Molenaar and others (1982) and by Molenaar and Sandburg (1983), but the present authors rate the energy resource potential as moderate, at certainty level $\mathrm{C}$.

\section{Geothermal Energy}

No hot springs or thermal anomalies are known in the study area. Although the iron-oxide stain and carbonate cement on rocks adjacent to fractures suggests fluid flow in fractures, no evidence of high temperature has been recognized. Small basalt flows and igneous intrusions of Quaternary age occur to the west of the study area, and an intrusive rhyolite is present at the King mine, less than a mile to the south. However, no such bodies, which could be a source for geothermal energy, are indicated by geophysical anomalies in the study areas. A low potential is recognized for geothermal energy in the study area, at a certainty level of $\mathrm{C}$.

\section{Coal}

Coal-bearing rocks (the Dakota Sandstone and Straight Cliffs Formation) once covered the study area, but 
almost all the Dakota and all the Straight Cliffs have been eroded from the area. There is no resource potential for coal, at certainty level $\mathrm{D}$.

\section{REFERENCES CITED}

Bell, Henry III, Kilbum, J.E., Cady, J.W., and Lane, M.E., 1990, Mineral resources of the Cockscomb and Wahweap Wilderness Study Areas: U.S. Geological Survey Bulletin 1748-A, $18 \mathrm{p}$.

Bendix Field Engineering Corporation, 1983a, Residual intensity magnetic anomaly profile map, Escalante National Topographic Map, Arizona/Utah: U.S. Department of Energy report GJM-416(83), 1 fiche. Available from U.S. Geological Survey, Books and Open-File Reports Section, Box 25425, DFC, Denver, CO 80225.

1983b, Residual intensity magnetic anomaly profile map, Cedar City National Topographic Map, Arizona/Utah: U.S. Department of Energy report GJM-427(83), 1 fiche. Available from U.S. Geological Survey, Books and OpenFile Reports Section, Box 25425, DFC, Denver, CO 80225.

Brown, S.E., and Hannigan, B.J., 1986, Mineral investigations of a part of the Paria-Hackberry Wilderness Study Area (UT-040-247), Kane County, Utah: U.S. Bureau of Mines Open File Report MLA 34-86, 25 p.

Cook, K.L., Bankey, Viki, Mabey, D.R., and DePangher, Michael, 1989, Bouguer gravity anomaly map of Utah: Utah Geological and Mineral Survey Map 122, scale 1:500,000.

Crock, J.G., Briggs, P.H., Jackson, L.L., and Lichte, F.E., 1987, Analytical methods for the analysis of stream sediments and rocks from wildemess study areas: U.S. Geological Survey Open-File Report 87-84, 35 p.

Crock, J.G., Lichte, F.E., and Briggs, P.H., 1983, Determination of elements in National Bureau of Standards Geological Reference Material SRM 278 obsidian and SRM 668 basalt by induction-coupled argon plasma-atomic emission spectrometry: Geostandards Newsletter, no. 7, p. 335-340.

Doelling, H.H., 1975, Geology and mineral resources of Garfield County, Utah: Utah Geological and Mineral Survey Bulletin 107,175 p.

Doelling, H.H., and Davis, F.D., 1989, The geology of Kane County, Utah--Geology, mineral resources, geologic hazards; with sections on petroleum and carbon dioxide by C.J. Brandt: Utah Geological and Mineral Survey Bulletin 124 and Map 121, 192 p., 10 pls., scale 1:100,000.

Dubyk, W.S., and Young, Patti, 1978, Preliminary evaluation of the uranium favorability in the Kaiparowits Plateau region, Garfield and Kane Counties, Utah: U.S. Department of Energy report GJBX-64(78) (prepared by Bendix Field Engineering Corporation), 28 p. Available from U.S. Geological Survey, Books and Open-File Reports Section, Box 25425, DFC, Denver, CO 80225.

Duval, J.S., 1983, Composite color images of aerial gamma-ray spectrographic data: Geophysics, v. 48, p. 722-735.

Geodata International, Inc., 1980, Aerial radiometric and magnetic survey, Cedar City National Topographic Map, Arizona/ Utah: U.S. Department of Energy report GJBX-93(80), 225 p., 120 fiche. Available from U.S. Geological Survey, Books and Open-File Reports Section, Box 25425, DFC,
Denver, CO 80225; computer-readable magnetic tape available from EROS Data Center, U.S. Geological Survey, Sioux Falls, SD 57198.

Geo-Life, Inc., 1980, Aerial radiometric and magnetic survey, Escalante National Topographic Map, Arizona/Utah: U.S. Department of Energy report GJBX-15(80), 183 p., 106 fiche. Available from U.S. Geological Survey, Books and Open-File Reports Section, Box 25425, DFC, Denver, CO 80225; computer-readable magnetic tape available from EROS Data Center, U.S. Geological Survey, Sioux Falls, SD 57198.

Goudarzi, G.H., compiler, 1984, Guide to preparation of mineral survey reports on public lands: U.S. Geological Survey Open-File Report 84-787, 42 p.

Gregory, H.E., 1948, Geology and geography of central Kane County, Utah: Geological Society of America Bulletin, v. 59 , no. 3, p. 211-248.

1951, The geology and geography of the Paunsaugunt region, Utah: U.S. Geological Survey Professional Paper 226, $116 \mathrm{p}$.

Gregory, H.E., and Moore, R.C., 1931, The Kaiparowits region-A geographic and geologic reconnaissance of parts of Utah and Arizona: U.S. Geological Survey Professional Paper 164, $161 \mathrm{p}$.

Grimes, D.J., and Marranzino, A.P., 1968, Direct-current arc and alternating-current spark emission spectrographic field methods for the semiquantitative analysis of geologic materials: U.S. Geological Survey Circular 591, 6 p.

Hackman, R.J., and Wyant, D.G., 1973, Geology, structure, and uranium deposits of the Escalante quadrangle, Utah and Arizona: U.S. Geological Survey Miscellaneous Geologic Investigations Series Map 1-744, scale 1:250,000.

Hageman, P.L., Adrian, B.M., Tumer, R.L., Vaughn, R.B., and Fey, D.L., 1990, Analytical results and sample locality map of stream-sediment, heavy-mineral concentrate and rock samples from the Paria-Hackberry Wilderness Study Area, Kane County, Utah (UT-040-247): U.S. Geological Survey Open-File Report 90-0472, 38 p., 1 pl.

Hintze, L.F., 1963, Geological map of southwestem Utah: Utah State Land Board, scale 1:250,000. Available from Utah Geological and Mineral Survey, Salt Lake City, Utah 84112

Hintze, L.F., and Stokes, W.L., 1964, Geologic map of southeastern Utah: Utah State Land Board, scale 1:250,000. Available from Utah Geological and Mineral Survey, Salt Lake City, Utah 84112.

Koirtyohann, S.R., and Khalil, Moheb, 1976, Variables in determination of mercury by cold vapor atomic absorption: Analytical Chemistry, 48, p. 136-139.

Lawson, A.C., 1913, The gold of the Shinarump at Paria: Economic Geology, v. 8, p. 434-446.

Levinson, A.A., 1980, Introduction to exploration geochemistry: Wilmette, Illinois, Applied Publishing, 924 p.

McCafferty, A.E., and Cady, J.W., 1987, Gravity survey data of seven wildemess study areas in southwest Utah, Kane and Garfield Counties, Utah: U.S. Geological Survey Open-File Report 87-200, 9 p. 
McKown, D.M., and Millard, H.T., Jr., 1987, Determination of uranium and thorium by delayed neutron counting; chapter I of Baedecker, P.A., ed., Methods for geochemical analysis: U.S. Geological Survey Bulletin 1770, p. I1-I12.

Molenaar, C.M., and Sandberg, C.A., 1983, Petroleum potential of wilderness lands in Utah; chapter K of Miller, B.M., ed., Petroleum potential of wildemess lands in the western United States: U.S. Geological Survey Circular 902, p. K1-K14.

Molenaar, C.M., Sandberg, C.A., and Powers, R.B., 1982, Petroleum potential of wilderness lands, Utah: U.S. Geological Survey Miscellaneous Investigations Series Map I-1545, scale 1:1,000,000.

Oakes, E., Wedow, H., Poling, R., and Voelker, A., 1981, Energy resource evaluation of wildemess study areas; the Bureau of Land Management's Cedar City district, Utah: Prepared for the U.S. Department of Energy Leasing Policy Development Office, p. 269, 270.

O'Leary, R.M., and Viets, J.G., 1986, Determination of antimony, arsenic, bismuth, cadmium, copper, lead, molybdenum, silver, and zinc in geologic materials by atomic absorption spectrometry using a hydrochloric acid-hydrogen peroxide digestion: Atomic Spectroscopy, 7, p. 4-8.

Peterson, Fred, and Pipiringos, G.N., 1979, Stratigraphic relations of the Navajo Sandstone to Middle Jurassic formations, southern Utah and northern Arizona: U.S. Geological Survey Professional Paper 1035-B, p. B1-B43.

Phoenix, D.A., 1963, Geology of the Lees Ferry area, Coconino County, Arizona: U.S. Geological Survey Bulletin 1137, $86 \mathrm{p}$.

Sargent, K.A., and Hansen, D.E., 1982 [1983], Bedrock geologic map of the Kaiparowits coal-basin area, Utah: U.S. Geological Survey Miscellaneous Investigations Series Map I-1033-I, scale 1:125,000.

Sargent, K.A., and Philpott, B.C., 1985, Geologic map of the Johnson quadrangle, Kane County, Utah, and Coconino County, Arizona: U.S. Geological Survey Geologic Quadrangle Map GQ-1602, scale 1:62,500.

Thompson, C.E., Nakagawa, H.M., and Van Sickle, G.H., 1968, Rapid analysis for gold in geologic materials, in Geological Survey research 1968: U.S. Geological Survey Professional Paper 600-B, p. B130-B132.

Thompson, J.R., 1989, Mineral investigation of additional parts of the Paria-Hackberry Wilderness Study Area (UT-040-247), Kane County, Utah: U.S. Bureau of Mines Open File Report MLA 34-89, 27 p.

U.S. Bureau of Mines and U.S. Geological Survey, 1980, Principles of a resource/reserve classification for minerals: U.S. Geological Survey Circular 831, 5 p. 

APPENDIX 


\section{DEFINITION OF LEVELS OF MINERAL RESOURCE POTENTIAL AND CERTAINTY OF ASSESSMENT}

\section{LEVELS OF RESOURCE POTENTIAL}

H HIGH mineral resource polential is assigned to areas where geologic, geochemical, and geophysical characteristics indicate a geologic environment favorable for resource occurrence, where interpretations of data indicate a high degree of likelihood for resource accumulation, where data support mineral-deposit models indicating presence of resources, and where evidence indicates that mineral concentration has taken place. Assignment of high resource potential to an area requires some positive knowledge that mineral-forming processes have been active in at least part of the area.

$M$ MODERATE mineral resource potential is assigned to areas where geologic, geochemical, and geophysical characteristics indicate a geologic environment favorable for resource occurrence, where interpretations of data indicate reasonable likelihood for resource accumulation, and (or) where an application of mineral-deposit models indicates favorable ground for the specified type(s) of deposits.

L LOW mineral resource potential is assigned to areas where geologic, geochemical, and geophysical charaderistics define a geologic environment in which the existence of resources is permissive. This broad category embraces areas with dispersed but insignificantly mineralized rock, as well as areas with little or no indication of having been mineralized.

N NO mineral resource potential is a category reserved for a specific type of resource in a well-defined area.

$U$ UNKNOWN mineral resource potential is assigned to areas where information is inadequate to assign a low, moderate, or high level of resource potential.

\section{LEVELS OF CERTAINTY}

A Available information is not adequate for determination of the level of mineral resource potential.

B Available information only suggests the level of mineral resource potential.

C Available information gives a good indication of the level of mincral resource potential.

D Available information clearly defines the level of mineral resource potential.

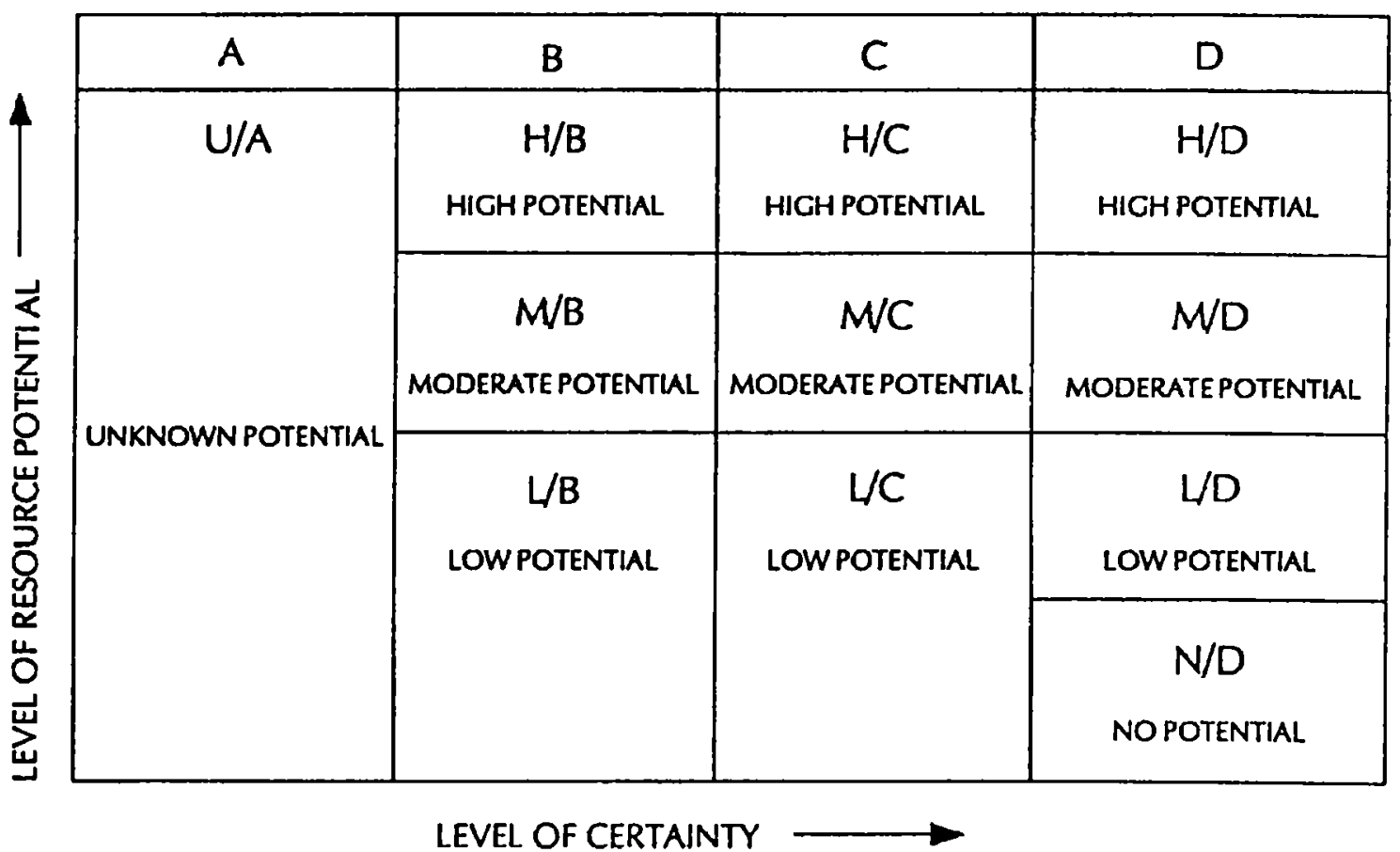

Abstracted with minor modificalions from:

Taylor, R.B., and Steven, T.A., 1983, Definition of mineral resource polential: Economic Ceology, v. 78, no. 6, p. 1268-1270.

Taylor, R.B., Stoneman, R.J., and Massh, S.P., 1984, An assessment of the mineral resource potential of the San isabel National Forest, south-central Colorado: U.S. Ceological Survey Bulletin 1638, P. 40.42.

Goudarzi, G.H., compiler, 1984, Guide to preparation of mineral survey reports on public lands: U.5. Ceological Survey Open-File Report 84-0787, p. 7, 8. 


\section{RESOURCE/RESERVE CLASSIFICATION}

\begin{tabular}{|c|c|c|c|c|c|}
\hline & \multicolumn{3}{|c|}{ IDENTIFIED RESOURCES } & \multicolumn{2}{|c|}{ UNDISCOVERED RESOURCES } \\
\hline & \multicolumn{2}{|c|}{ Demonstrated } & \multirow{2}{*}{ Inferred } & \multicolumn{2}{|c|}{ Probability Range } \\
\hline & Measured & Indicated & & Hypothetical & Speculative \\
\hline ECONOMIC & Res & & Inferred Reserves & & \\
\hline $\begin{array}{l}\text { MARGINALLY } \\
\text { ECONOMIC }\end{array}$ & Margina & Peserves & $\begin{array}{c}\text { Inferred } \\
\text { Marginal Reserves }\end{array}$ & & \\
\hline $\begin{array}{c}\text { SUB- } \\
\text { ECONOMIC }\end{array}$ & $\begin{array}{l}\text { Demol } \\
\text { Subeconon }\end{array}$ & $\begin{array}{l}\text { Resoded } \\
\text { Resources }\end{array}$ & $\begin{array}{l}\text { Inferred } \\
\text { Subeconomic } \\
\text { Resources }\end{array}$ & & \\
\hline
\end{tabular}

Major elements of mineral resource classification, excluding reserve base and inferred reserve bese. Modified from McKelvey, 1972 , Mineral resource estimates and public policy: American Scientist, v.60, p.32-40, and U.S. Bureau of Mines and U.S. Geological Survey, 1980, Principles of a resource/reserve classification for minerals: U.S. Geological Survey Circular 831, p.5. 
GEOLOGIC TIME CHART

Terms and boundary ages used by the U.S. Geological Survey in this report

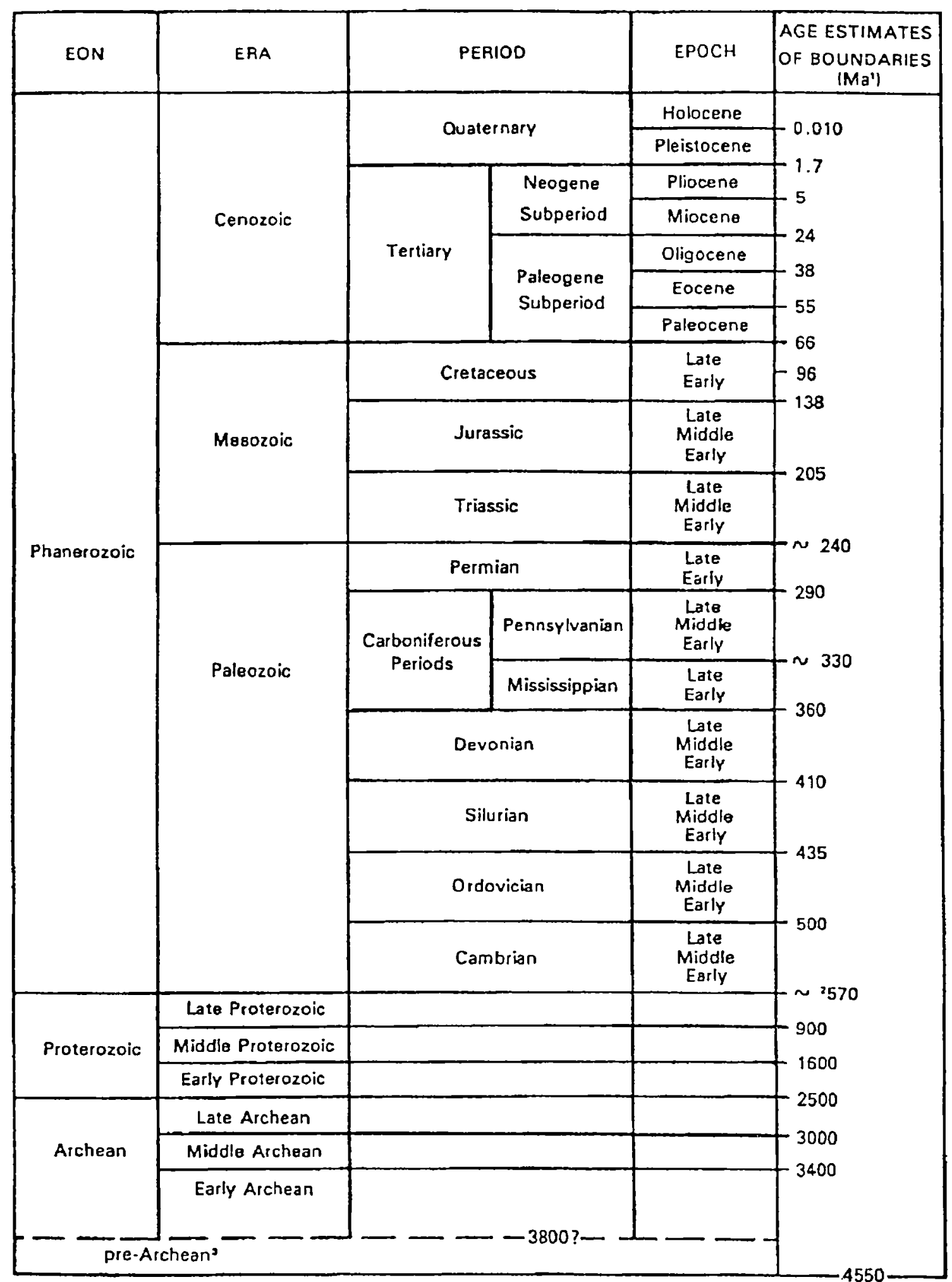

'Milions of years prior to A.D. 1950.

${ }^{2}$ Rocks older than 570 m.y. also. called Precambrian, a time term without specific rank.

Informal time term without specific rank. 


\section{Mineral Resources of Wilderness Study Areas- The Cockscomb Region, Utah}

This volume was published as separate chapters $A-B$ 


\section{U.S. DEPARTMENT OF THE INTERIOR MANUEL LUJAN, JR., Secretary \\ U.S. GEOLOGICAL SURVEY \\ Dallas L. Peck, Director}

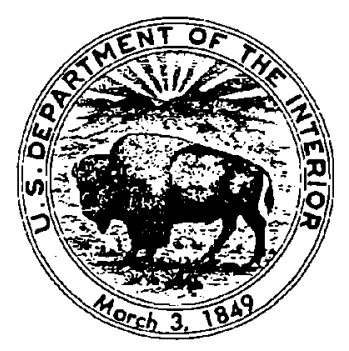




\section{CONTENTS}

[Letters designate the chapters]

(A) Mineral Resources of the Cockscomb and Wahweap Wilderness Study Areas, Kane County, Utah, by Henry Bell III, James E. Kilburn, John W. Cady, and Michael E. Lane

(B) Mineral Resources of the Paria-Hackberry Wilderness Study Area, Kane County, Utah, by Henry Bell III, Alfred L. Bush, Robert L. Tumer, John W. Cady, S. Don Brown, Brian J. Hannigan, and John R. Thompson 




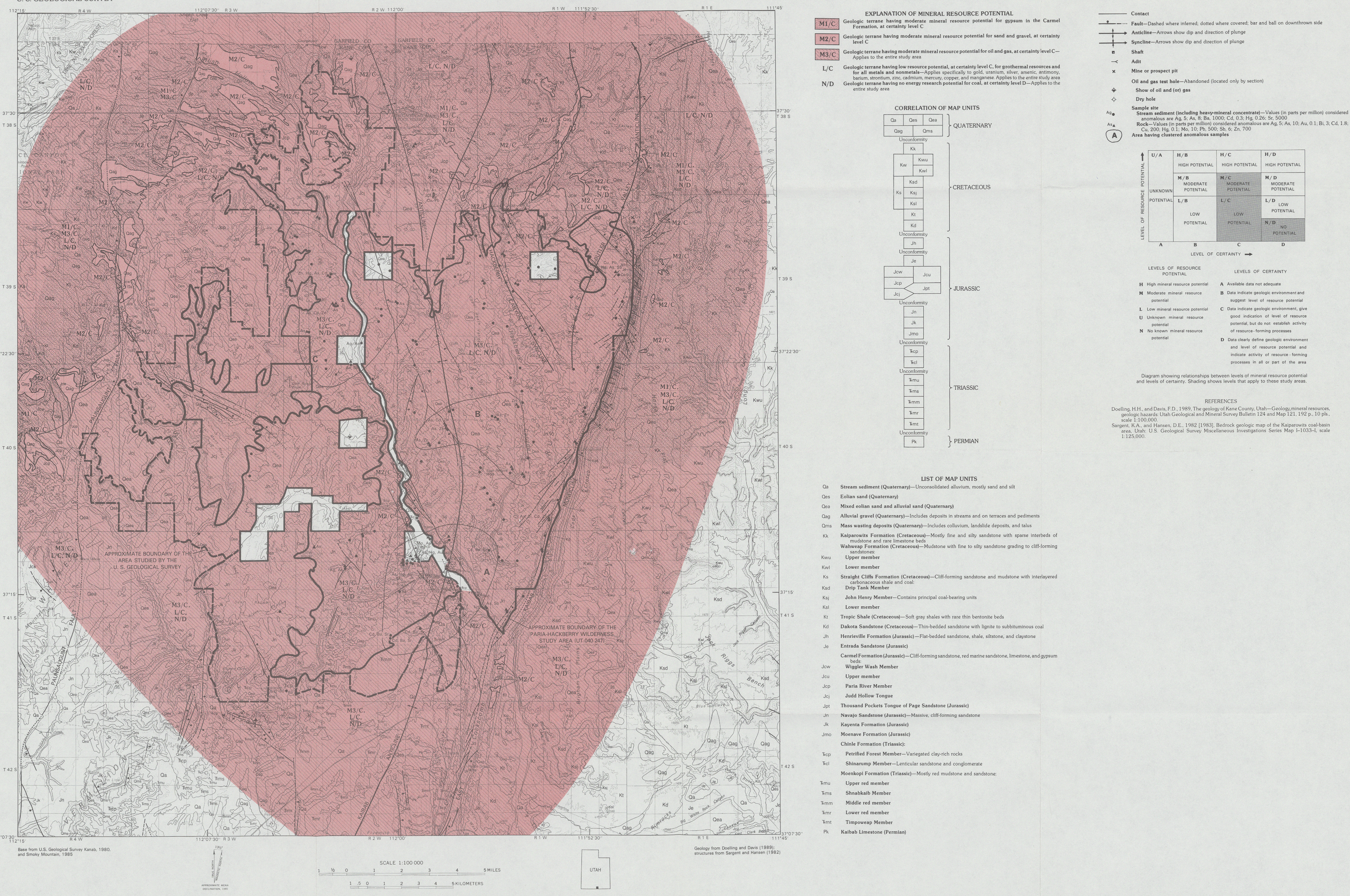

(4)

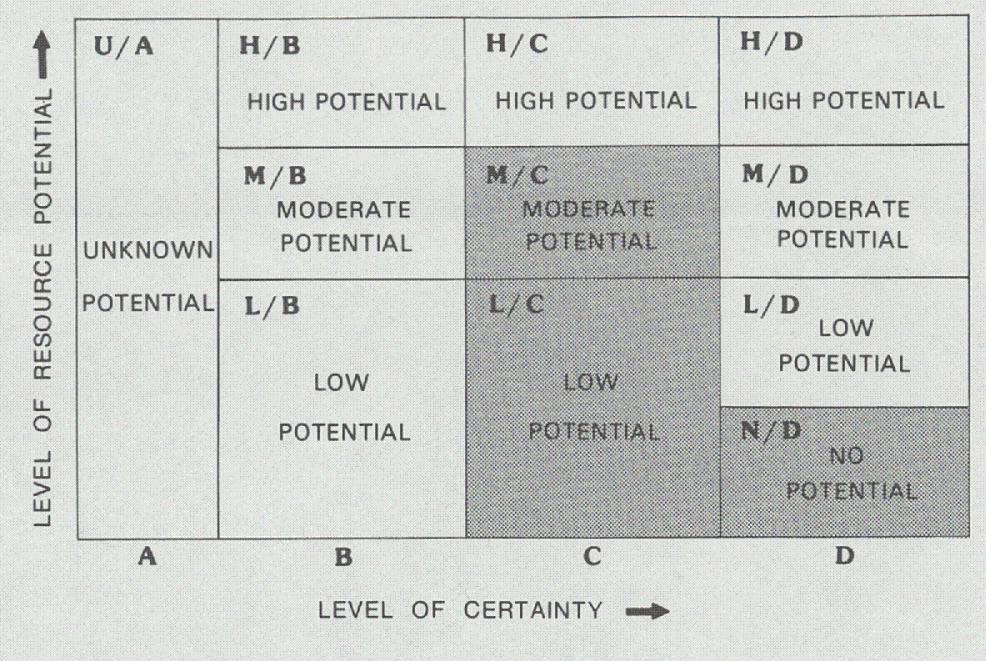

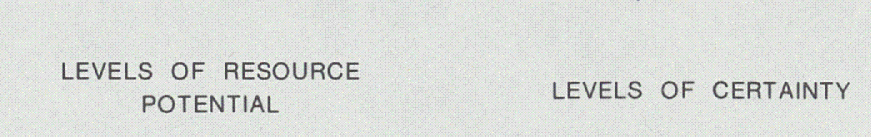

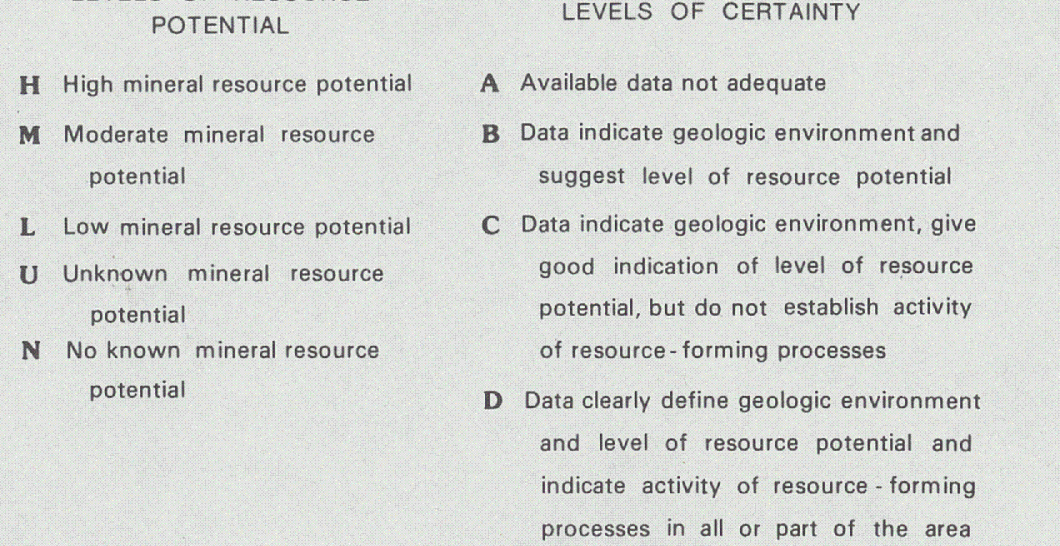

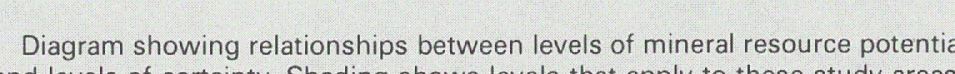

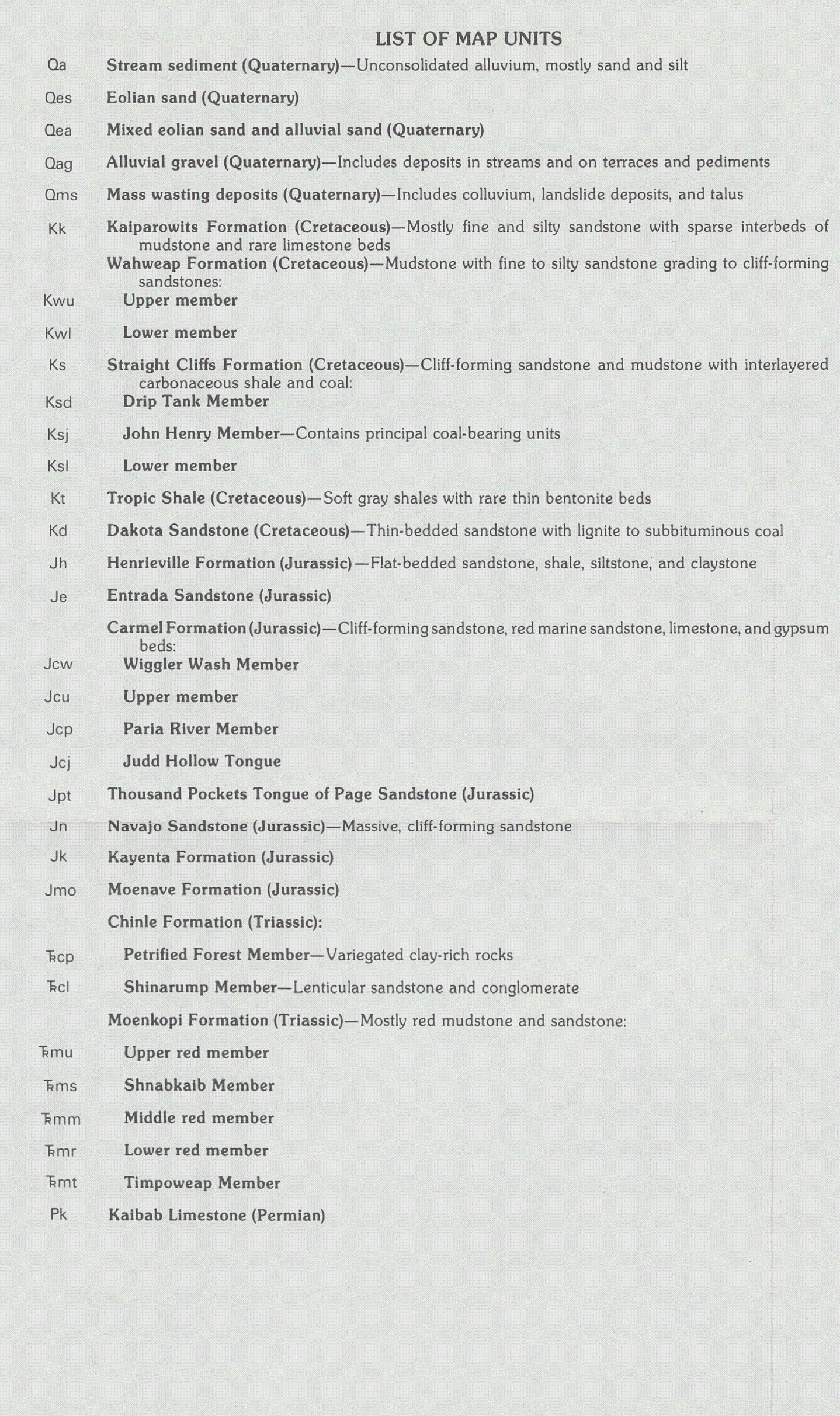


